\title{
Diagnostic tests and their application in the management of soil- and water-borne oomycete pathogen species
}

\author{
A.J. Wakeham \& T.R. Pettitt \\ Institute for Science \& the Environment, University of Worcester, Worcester, UK
}

Keywords: disease management, diagnosis, crop pathogens,

\section{Correspondence}

\author{
A.J. Wakeham, Institute for Science \\ \& the Environment, Charles Darwin Building, \\ University of Worcester, \\ Henwick Grove, Worcester, WR2 6AJ, UK \\ Email: a.wakeham@worc.ac.uk
}

\begin{abstract}
Oomycete diseases cause significant losses across a broad range of crop and aquaculture commodities worldwide. These losses can be greatly reduced by disease management practices steered by accurate and early diagnoses of pathogen presence. Determinations of disease potential can help guide optimal crop rotation regimes, varietal selections, targeted control measures, harvest timings and crop post-harvest handling. Pathogen detection prior to infection can also reduce the incidence of disease epidemics. Classical methods for the isolation of oomycete pathogens are normally deployed only after disease symptom appearance. These processes are often-time consuming, relying on culturing the putative pathogen(s) and the availability of expert taxonomic skills for accurate identification; a situation that frequently results in either delayed application, or routine 'blanket' overapplication of control measures. Increasing concerns about pesticides in the environment and the food chain, removal or restriction of their usage combined with rising costs have focussed interest in the development and improvement of disease management systems. To be effective, these require timely, accurate and preferably quantitatve diagnoses. A wide range of rapid diagnostic tools, from point of care immunodiagnostic kits to next generation nucleotide sequencing have potential application in oomycete disease management. Here we review currently-available as well as promising new technologies in the context of commercial agricultural production systems, considering the impacts of specific biotic and abiotic and other
\end{abstract}


important factors such as speed and ease of access to information and cost effectiveness.

\section{Introduction}

The oomycetes are a large group of fungus-like microorganisms, with representatives in virtually every terrestrial, marine and freshwater habitat worldwide. A significant proportion of the oomycetes are parasitic, colonising and causing disease in a very diverse range of organisms from other protists to higher plants and animals (Beakes et al., 2012). Oomycetes cause significant losses across a broad range of agribusiness commodities worldwide, varying from the infamous and still highly destructive Phytophthora 'blight' of potatoes (Bourke, 1991), to Saprolegnia 'saprolegniosis' in farmed fish (Van West, 2006). In addition to these highly destructive diseases, many oomycete pathogens cause yield losses by attritional damage, for example in cereals where Pythium spp. causing lateral root necrosis have been dubbed the 'common cold of wheat' (Cook \& Veseth, 1991), as well as storage rots (Cullen et al., 2007), and declines in infected produce quality (Guehi et al., 2008).

Economic losses resulting from disease development can be reduced by accurate and early detection of pathogens. Accurate although not necessarily overly precise diagnosis (in many instances identification to genus is quite sufficient) is essential for the selection of appropriate control/management measures and timings, whilst rapid detection improves the efficacy of treatments and can allow interception and avoidance strategies to be effectively deployed. Unfortunately, methods currently commonly adopted for the isolation and diagnosis of many pathogens are slow and normally, only deployed after disease symptoms have become apparent. In agricultural and horticultural production where profit margins are narrow and a policy of 'zero-tolerance' of disease expression in crop products has generally been applied by retailers, a culture of blanket fungicide applications has developed. With increasing global pressure to reduce pesticide inputs this approach will no longer be tolerated. In Europe, the recent introduction of the Sustainable Use Directive (SUD) (http://ec.europa.eu/food/plant/pesticides/sustainable use pesticides/index en.htm) requires producers to demonstrate that they have taken alternative integrated pest and disease management (IPDM) measures to prevent pest \& disease development before the use of spray applications of insecticides and/or fungicides. This situation will increase the pressure on producers and their staff to monitor and identify potential disease and pest problems quickly.

Pathogen detection prior to infection can reduce or even prevent disease epidemics by identifying when and where treatments and avoidance measures need to be applied. The timely detection and identification of economically important diseases in a commercial production environment provides the initial key to drive a successful and informed control strategy. It is however only part of the solution, the success of which will depend on how the information is evaluated and incorporated within integrated disease management systems (IDMS). Here we describe currently- 
available and emerging techniques for the practical detection and diagnosis of oomycete pathogens and their potential role in the development of IDMS for soil and water-borne oomycetes.

\section{Baiting, isolation and direct culturing of live propagules and identification by morphological characters}

Conventional plating of plant tissue, water filtrate or soil suspensions onto semiselective agars containing antibiotics is a simple and useful procedure for isolating and identifying Pythium, Phytophthora and Aphanomyces species (Papavizas \& Ayers, 1974; Ribeiro, 1978; Tsao, 1983; Hong et al., 2002; Pettitt et al., 2002). Unfortunately, these methods often tend only to be used after disease symptoms have been observed and even then take valuable time to implement and interpret. The detection methods commonly used are those of baiting, culture plating, or a combination of both (Pittis \& Colhoun, 1984). Whilst these procedures are useful and relatively simple to carry out, their accurate interpretation requires much experience and skill and they can give variable results, especially with plant tissues, or where pathogen propagules have entered dormancy (Hüberli et al., 2000; Collins et al., 2012). Nevertheless, they do provide direct estimates of pathogen viability and allow the collection of representative cultures of live pathogen (Cooke et al., 2007) that can be used for determinations of pathogen 'fitness' by in vitro measurement of parameters such as sporulation, growth characteristics, pathogenicity, virulence and resistance to fungicides. Direct quantitation of pathogen propagules or inoculum can be achieved from soil by dilution plating (Tsao, 1983), from water by membrane filtration-resuspension plating (Pettitt et al., 2002; Büttner et al., 2014) and from plant tissues by comminution followed by plating dilutions onto selective agar plates and counting the resulting colonies (Pettitt \& Pegg, 1991). Baiting techniques have been used since the 1960s for both Phytophthora and Pythium detection in water and in soils (Werres, et al., 2014), and can be very effective, although of variable sensitivity, as they are dependent on the quality and physiological state of the plant tissues being used as baits (Themann et al., 2002; Hüberli et al., 2000). Baiting procedures are also likely to give a skewed picture of the potential pathogens present (Arcate et al., 2006) and are really best deployed for the detection of specific pathogen species using specific plant tissues. Nevertheless, they can provide confirmation of disease presence and have a limited capacity for quantitation e.g. by the most probable number (MPN) method (Tsao, 1960 \& 1983). The main drawback of these 'conventional' techniques is the time required to generate information; measured in days rather than hours, which is often too slow to assist with making on-site disease management decisions. This has led to a situation of routine, often prophylactic deployment of fungicides/oomyceticides generally leading to ineffective targeting and overuse, and consequently resulting in the build-up of widespread fungicide resistance (White \& Wakeham, 1987) and even lost efficacy resulting from enhanced fungicide degradation (Kenny et al., 2001). The current best practice 'conventional' diagnostic tests for root and stem rot oomycetes take upwards of $24 \mathrm{hrs}$ with float tests (Ribeiro, 1978; Dhingra \& Sinclair, 1995 - specific examples: 24h Phytophthora 
in strawberry crowns, Pettitt \& Pegg, 1994; overnight in HNS roots Pettitt et al., 1998) and between 3 and 10 days by conventional agar plating methods (Fox, 1993).

\section{Molecular Approaches to Disease Diagnosis}

Pioneering work in the medical field during the latter decades of the last century has provided an array of molecular-based techniques suitable for development of rapid diagnostic test procedures. Many of these have been commercialised to provide simple on-site diagnostic tests for medical use (Posthuma-Trumpie et al., 2009). The defence industry has also provided invaluable input with, highly-sensitive and accurate systems for the detection and evaluation of biological warfare agents. For example the RAZOR ${ }^{\circledR}$ EX Anthrax Air Detection System. These emerging technologies are increasingly moving the emphasis towards nanobiotechnology (Jeong-Yeol \& Bumsang, 2012). There is a real expectation that mobile phones will provide a global laboratory platform for many of these approaches (Ozcan, 2014). The molecular techniques considered here fall into two broad categories: immunologically-based assays and nucleotide-based assays, although there is overlap, with some procedures combining techniques from both categories.

\section{Immunoassays:}

Background:

Following the work of Yalow \& Berson (1959), using anti-insulin antibodies to measure hormone levels in blood plasma, immunological assay systems have provided an important contribution to analytical diagnostic test development. With an array of different labels and detection systems available, measurement of the antibody (immunological diagnostic probe) and antigen (target analyte/disease propagule) can be made quantitative or qualitative. This approach has been found to be highly transferrable, from commercial centralised laboratories offering tests with high throughput, specificity and sensitivity (for example the enzyme-linked immunosorbent assay (ELISA) Harlow \& Lane, 1988) to simple point of care (POC) test systems operated by non-specialists. The latter being designed to be used at or near the site where a problem is located, do not require a permanent dedicated space and can provide results quickly (generally within minutes). They can provide quick feedback in many sorts of investigations, for example; enzyme analysis, drugs of abuse, infectious agents, toxic compounds, metabolic disorders, allergens, ovulation and pregnancy testing.

\section{Polyclonal antibodies:}

Using polyclonal antisera (antibodies isolated from blood serum of immunised animals), immunoassays were first deployed in a phytopathological context for the detection of viruses and bacterial plant pathogens in infected plant tissues (Voller et al., 1976; Clark \& Adams, 1977; Nome et al., 1980). The potential of this approach for fungi was demonstrated by Casper \& Mendgen in 1979. Later, Johnson et al. (1982) reported the diagnosis of Epichloe typhina colonization in tall fescue (causing 
toxicity syndrome in cattle). Nevertheless, discrimination of the pathogen was limited to genus level in these early studies, and whist the techniques were being successfully applied worldwide for screening plant material for viruses (Raju \& Olson, 1985; Burger \& Von Wechmar, 1988), the poor specificity achieved to structurally more complex fungal and oomycete pathogens (Drouhet, 1986) hampered the early development of immunologically accurate diagnostic probes for commercial applications (Mendgen, 1986, Barker \& Pitt, 1988).

As with fungi, the oomycetes share a complex array of antigenic sites that can induce a highly immunogenic and immuno-dominant response in the immunised animal. These include carbohydrate and protein complexes. For example, the Phytophthora cellulose binding elicitor lectin (CBEL-1), which plays an important role as a cell surface biomarker (pathogen associated molecular pattern (PAMP)) (Larroque et al., 2013). Mannose-containing heteroglycans such as galactomannans and rhamnomannans have also been identified as important derivatives of cell wall substances with importance towards immunogenic dominance. Enzymatic digestion and competitive inhibition tests demonstrate that galactosyl residues with $\beta$-linkages are immunodominant for Aspergilus, Geotrichum and Cladosporium antigens. Mannosyl residues with a-linkages provide immunodominance for Mucor antigens (Tsai \& Cousin, 1993). The structure and complexity of these pathogens can thus lead to the production of antibodies able to bind selectively to both related and nonrelated species (Mohan 1989a \& b; Notermans \& Soentoro, 1986; Da Silva Bahia et al., 2003; Viudes, et al., 2001; Priestley \& Dewey, 1993). This attribute can reduce specificity, consequentially new antibodies always need to be thoroughly screened against a range of target and non-target species when developing tests for specific pathogens/diseases.

\section{Monoclonal antibodies:}

With the advent of hybridoma technology (Köhler \& Milstein 1975) there has been capability to generate highly specific monoclonal antibodies (MAbs, a single antibody type) which can bind selectively to complementary determining regions (CDRs) of pathogen targets. A similar approach has been adopted using antibody engineering (phage display technologies) to provide single-chain antibody variable fragments (scFvs) (Arap, 2005). Targeted to single epitope sites (CDRs), these diagnostic probes provide the opportunity to discriminate not only between groups of organisms, but also between different genera, species, isolates, and possibly life cycle stages of pathogenic fungi and oomycetes (Dewey et al., 1990; Priestley \& Dewey, 1993; Keen \& Legrand, 1980; Hardham et al., 1986, Arap, 2005).

For oomycetes, the ability to identify molecules at a specific stage in a pathogen's life cycle (e.g. zoospores or cysts) has been reported (Estrada-Garcia et al., 1990). Whilst this ability is desirable for detailed epidemiological research, such probe specificity does have the potential to be problematic in commercial test development. For example, where pathogens with multiple infective life cycle stages can co-exist. 
For this reason the organism and the application of the test should be well understood. To overcome these issues the combination of antibody types (monoclonal and polyclonal) has been found beneficial to achieve an appropriate test specificity and/or sensitivity. Equally, where non-specific binding to host tissue is observed, the use of antibody combinations for capture and labelling of target antigens (target disease component) has also been found useful (Priestley and Dewey, 1993). These early successes have resulted in a rapid expansion of MAbbased immunoassay diagnostic procedures for the qualitative and quantitative measurement of fungal and oomycete pathogens (Dewey et al., 1993, KarpovichTate et al., 1998; Wakeham \& Kennedy, 2010; Wakeham et al., 2012; Dewey et al., 2013 \& Thornton \& Wills, 2013). Availability of these probes from maintained cell lines may in the future prove a useful resource for fundamental host-pathogen interaction studies.

\section{Enzyme-linked immunosorbent assay:}

In test development, Clark and Adams (1977) introduced the use of the enzymelinked immuno-sorbent assay (ELISA) for the quantitation of plant viruses in host tissues. This system is now used routinely in laboratories worldwide to provide high throughput, quantitative measurement of contamination/infection by viral, bacterial, fungal and oomycete plant pathogens in a range of environmental samples (Singh \& Singh, 1995, Fang \& Ramasamy, 2015). For viral and bacterial samples many of the commercial ELISA systems use a double antibody sandwich format (DAS ELISA). This format can prove useful in capture and isolation of target pathogens from complex materials and the attachment of a second antigen-specific labelled antibody, can provide improved specificity. A second type of ELISA is the plate trapped antigen (PTA ELISA). This assay is often reported for use in the diagnosis of fungal and oomycete plant pathogens (Dewey and Thornton, 1995, Wakeham et al., 2004). Antibodies raised to these targets are often directed to glycoprotein structures which bind readily to the solid phase surface of an ELISA process and so do not require a capture antibody (Kemeny, 1991; Nicolaisen \& Justesen, 2007). Also, many soluble glycoprotein structures do not lend functionally to the binding of two antibody types at one time. Where these structures prove heat stable, this characteristic can be used in sample treatment to mitigate issues of antibody crossreactivity (Dewey et al., 1997). The third type of ELISA system used routinely is the competitive ELISA (c ELISA). This format is used extensively in the detection of mycotoxins in food, pesticides in ground water and has been reported for the measurement of some soil-borne fungi and oomycetes in plants and soil. However, the development of such assay systems for the measurement of plant pathogens in environmental samples, especially soil, is particularly challenging. A good example of this problem is seen with carrot cavity spot caused in the UK by Pythium violae and $P$. sulcatum (Lyons \& White, 1992; Hiltunen \& White, 2002). A largely cosmetic disorder, cavity spot can rapidly render carrot crops unmarketable close to time of harvest, and since carrot crops are often grown in changing locations under contract and both species of Pythium have broad host ranges, a reliable test for the disease 
risks of new fields is highly desirable. Based on the work of Lyons \& White (1992), a laboratory diagnostic competitive ELISA test was developed to monitor pathogen oospore concentrations in soils (White et al. 1995, 1996, 1997). Although this procedure showed some promise, results for oospore detection did not always tie up well with subsequent observed disease. Such results might in part be explained by variation in environmental conditions during cropping as cavity spot disease incidence and severity can increase rapidly in wet conditions (Suffert \& Montfort, 2007), but other factors may also have confounded test results. For example, the assay used polyclonal antiserum, and since many oomycete species are found naturally-occurring in soil, the antibodies used may have reacted with these or antigenically related species. Also, there is the potential of soil inhibitors; assay sensitivity and non-specific binding have been reported for other soil immunoassays (Kageyama et al. 2002, Otten et al. 1997). Finally, soil composition could have an impact, and with irregular distributions of pathogen propagules creating problems for accurate, representative sampling (Phelps et al., 1991).

\section{Concentrating samples to assist detection:}

To overcome these potential challenges to immunoassay efficacy, workers have attempted to develop simple and efficient extraction systems for isolation of target pathogens from soil. However this process has proven one of the biggest hurdles in the development of quick and sensitive plant pathogen diagnostic immunoassays (Dewey \& Thornton, 1995). Many soil tests still resort to the use of a biological amplification stage (soil-baiting) to provide target analytes at readable concentrations (Yuen et al. 1993; Thornton et al. 2004). A beneficial consequence of this approach is that such tests are able to provide valuable information on viability of the target organism. However, they are also generally reduced to being qualitative or semiquantitative and can end up proving as time-consuming as conventional mediabased isolation tests.

Another approach has been the inclusion of a pre-treatment, for example drying, grinding, centrifugation or floatation processes, to recover pathogen resting structures. Unfortunately, these processes often prove laborious, lack economy of scale and, require considerable laboratory space prior to analysis (Wallace et al., 1995; Wakeham \& White, 1996; Miller et al., 1997), and the development of a rapid, highly sensitive and inexpensive assay becomes somewhat irrelevant if the extraction process is lengthy, laborious and costly in time and labour. For this reason, simple and rapid processes to isolate and concentrate disease propagules from soil are still being actively sought. Separation of bacteria has been successfully achieved by immuno-magnetic capture, with isolation, concentration and detection reported from contaminated feedstuffs (Johne et al. 1989; Mansfield \& Forsythe, 1993), faeces (Luk and Lindberg, 1991) aquatics (Bifulco \& Schaefer, 1993) and soil (Mullins et al. 1995). Recently, this approach has been adopted to isolate and concentrate resting spores of the clubroot plant pathogen from infested UK 
horticultural and agricultural soils (Kennedy \& Wakeham, 2013). Monoclonal antibodies specific to Plasmodiophpora brassicae (causal agent of clubroot) and conjugated to super paramagnetic spheres have been used to 'fish' soil for $P$. brassicae resting spores. The labelled spores are isolated from the soil matrix and concentrated by exposure to a magnetic field. Quantitation of the isolated spores is determined either by quantitative polymerase chain reaction (qPCR) (Lewis, 2011) or by using an on-site ten minute lateral flow (immuno-chromatographic) test (Wakeham et al. 2012).

Prospects of multiplex testing of complex environmental samples: The magnetic capture concept has been developed to provide immuno-array tests capable of multiplex testing for more than one pathogen. Test platforms like the magnetic microsphere capture immunoassay system (Luminex MAGPIX technology) can be used to detect multiple plant pathogens in complex environmental samples such as soil. This system can deploy 50 sets different fluorescence colour coded magnetic microspheres, each of which can be coated either with target analyte or a target pathogen-specific probe. Using a 96 well ELISA format, samples for testing are aliquoted $(20-100 \mu \mathrm{l}$ per well). Within each well there is the potential to deploy all 50 bead types at once, with each seeking and binding to a specific homologous target pathogen analyte. By applying a magnetic field, the beads with bound target material can be withdrawn from the sample and retained and separated from potential assay inhibitors. After this step an ELISA process is carried out and the magnetic sphere bound target analyte is identified by linking with a fluorophore ( $R$ phycoerythrin) conjugated detector antibody. The MAGPIX system is able to identify the colour-coded magnetic bead and measure the fluorescence of the detector antibody to provide quantitation of multiple target pathogens in a sample. This approach provides a versatile multiplexing platform capable of performing qualitative and quantitative analysis of up to 50 target analytes in a single reaction volume and, in a variety of sample matrices. The assay time of the microsphere immunoassay (1 $\mathrm{hr}$ ) is much shorter than for a standard ELISA system (approx. 4hr). There have been several reports using this new technology to detect foodborne pathogens and toxins (Kim et al., 2010), three potato viruses in infected host tissues (Bergervoet et al., 2008) and a multiplex seed screening assay, simultaneously detecting four important plant pathogens: the blotch bacterium (Acidovorax avenae subsp. citrulli), and three viruses; chilli vein-banding mottle virus, watermelon silver mottle virus and melon yellow spot virus (Charlermroj et al., 2013). This platform should prove highly versatile for epidemiological studies and crop clinic work assaying for, isolating, concentrating and quantifying multiple plant pathogens in potentially complex samples, such as soil, plants or water, at moderate cost.

\section{On-site testing}

Point of care assays (POCs), originally developed for medical applications have successfully been adapted to achieve reasonably accurate diagnoses of some plant diseases. An early example of this process was reported by Agri-Diagnostics 
Associates who developed flow through tests for detection of Phytophthora, Pythium and Rhizoctonia species on root, stem and leaf samples (Miller et al. 1990; Ellis \& Miller 1993). Variants, for example immuno-chromatographic test strips (Wong \& Tse, 2009) which are also known as lateral flow devices (LFD), are available worldwide for on-site testing of a range of viral, bacterial, fungal and Oomycete plant pathogen infections (e.g. www.neogen.com; http://www.envirologix.com; www.pocketdiagnostic.com). One of the earliest LFD tests for a fungus was the monoclonal antibody test developed for Botrytis spp. (Dewey \& Yohalem, 2007; Dewey et al., 2008 \& 2016). LFD tests comprise a carrier material containing dry reagents that are activated by applying a liquid sample. Movement of this liquid allows passage across various zones where molecules have been attached that exert specific interactions with target analytes. Results are usually generated within 5-10 minutes with the formation of a control and test line as appropriate to the sample and the test type (Figure 1). They are designed for single use, can be quantitative in measurement with a suitable reading device and a calibration curve (Wong \& Tse, 2009), and are capable of providing a limited multiplex test platform. In plant protection LFDs are increasingly used to provide a first line rapid defence screen. This application is amply demonstrated in forestry disease management where a Phytophthora genus-specific test device has been used in the UK by the Animal and Plant Health Agency's (APHA) Plant Health and Seed Inspectorate (PHSI) to detect and monitor the notifiable oomycete pathogens Phytophthora kernoviae and $P$. ramorum, the causal agent of sudden oak death and dieback/leaf blight in a range of tree, shrub, and herbaceous species. Initial positive diagnosis of the pathogen has enabled the effective management of the disease on horticultural nurseries by immediate quarantine and containment measures (Kox et al., 2007; Lane et al., 2007). Once a sample is identified as a potential risk from infestation confirmatory tests are undertaken to fully characterize the strains involved using DNA-based molecular techniques (www.fera.defra.gov.uk/plants/publications/documents/factsheets/pramparks.pdf). LFD tests have also been successfully used as quality control diagnostic tools. For example, rapid on-site detection of Fusarium mycotoxins using rapid on-site monoclonal antibody immunoassays specific to fusarins, T-2 toxin, zearalenone (F-2 toxin) and DON (Barno-Vetro et al., 1994; Casale et al., 1988; De Saeger \& Van Peteghem, 1996; Maragos et al., 2008), can quickly identify levels of contamination in cereal crops. Envirologix, under their QuickTox label (http://www.envirologix.com) supply a range of lateral flow tests to provide quantitative and traceable test results for mycotoxins in commodity grains. Within this product range a lateral flow device is also available to rapid determine levels of stable Botrytis antigens in table and dessert wines (Dewey et al., 2013). Lateral flow assay systems have also been developed and used to track horticultural biocontrol agents. Using a monoclonal antibody probe, active propagules of Trichoderma species can be detected in soil samples within 15 min of antigen extraction. These devices have also been used to detect oomycete animal-, and human-pathogens (Thornton \& Wills, 2013). 
Potential limitations of POC immunoassays:

Although the single step POC immunoassay has its strengths there are potential weaknesses of the test format (Posthuma-Trumpie et al., 2009). As with nucleotide based detection assays, the total sample volume that can be applied to this type of test is small (aprox. 100 $\mu$ l) potentially limiting sensitivity. As mentioned above, this problem may be addressed by pre-extraction treatments such as immuno-magnetic capture, although additional sample processing adds a level of complexity and detracts from the simplicity and speed of the single-step test approach. Application of the sample to the test is often drop-wise and this method has the potential to lead to a level of imprecision, especially if tests are being measured quantitatively using a reading device. In complex environmental samples, for example soils, food, or estuarine water, there is the capacity for the test strip to become blocked and inhibit the assay process. These problems can be reduced by incorporating pre-filtration materials into the lateral flow format, whilst sample volume issues can be addressed to some extent by deploying a range of sample pad sizes and formulations that allow increased volumes to be held prior to the immunoassay stage (www.millipore.com/diagnostics; www.whatman.com/DiagnosticComponents).

Dipstick and zoospore trapping immunoassays:

Although lateral flow tests (LFDs) have been found useful to quickly determine oomycete infections, available commercial tests are limited, by the antibodies used, in their ability to discriminate soil and water-borne oomycete pathogens at the species level. For Phytophthora, this situation is perhaps not so troublesome, as indicated above. However, it is highly problematic for Pythium species, a significant proportion of which are saprophytic, frequently found in cultivations and not pathogenic to crops (Van der Plaats-Niterink, 1981). In addition, at least four species, Pythium oligandrum, P.nunn, $P$. perioplocum and $P$. acanthicum, are aggressively mycophagous and therefore potentially beneficial in disease control (Ali-Shtayeh \& Saleh, 1999; Martin \& Hancock, 1987; Paulitz, et al., 1990: Vallance et al., 2009; White et al., 1992). The efficacy of these tests has also not yet been demonstrated for some environmental samples (e,g. growing substrates) or for the pre-symptomatic infection of plant material, although their use in conjunction with plant tissue baits has been used in irrigation water tests with some promise (Wedgwood, 2014). Importantly, these tests as they stand fail to distinguish between live and dead pathogen propagules, negating their value in assessing pathogen kill in measurements of the efficacy of pathogen control treatments. Cahill \& Hardham (1994) overcame this shortcoming to some extent with Phytophthora cinnamomi by exploiting zoospore chemotaxis and developed a 'dipstick' test which could be carried out in water and on-site by unskilled operators. However, often only a limited proportion of the total number of zoospores present in a water sample is detected using this method (Pettitt et al., 2002). It may also be wise to include a step inducing cyst germination to prove viability as opposed to relying solely on chemotaxis (or apparent chemotaxis), since apple bait pieces were found to pick up non-viable pathogen material under comparable circumstances (Wedgwood, 2014). This 
limitation could be very important in irrigation water supply where the number of zoospores per unit volume may be very low. Other workers have tried to overcome the problem by the development of a zoospore trapping immunoassay (ZTI Wakeham et al., 1997). This process concentrates material from irrigation water by filtration onto a membrane. Following a short incubation with a selective medium, the viable zoospore-germlings, if present, can be visualised using a specific antibody probe conjugated to a coloured marker (see Figure 2). To date this assay is one of the most sensitive test procedures to have been successfully deployed in routine water assessments for the measurement of viable oomycete propagules (Pettitt et al., 2002; Bandte \& Pettitt, 2014).

Improving LFD specificity using nucleic acid-based techniques:

Where specificity is problematic, LFD POC tests can be used in combination with nucleic acid molecular techniques (nucleic acid lateral flow (NALF)) to provide an onsite solution. This approach using loop-mediated isothermal amplification (LAMP, Notomi et al., 2000), has been applied for the detection of the oomycete pathogens Phytophthora ramorum and P. kernoviae from infected plant tissue (Tomlinson et al., 2010). After application to a chromatographic LFD test strip, which can also act as a preliminary genus-specific screen for Phytophthora, DNA is isolated and extracted from the membrane in $<5$ min with manual shaking in a small vial containing an extraction fluid. After extraction and applying LAMP, the target DNA is amplified using labelled specific primers. Detection of these labelled amplicon products is performed in a lateral flow test stip. Each of these steps (manual shaking to disrupt the sample before application onto the membrane, placing a section of the membrane into pre-prepared LAMP reaction mix and incubation in a heated block or water bath, and dilution of the LAMP reaction and application onto the chromatographic test strip) is deemed as sufficiently simple to potentially allow this method to be performed outside a conventional laboratory facility without extensive prior training. A result can be obtained in just over an hour. A LAMP assay for the detection of plant DNA (cytochrome oxidase gene) can be used in conjunction with pathogen-specific assays to confirm that the assay is working when a negative test results (Tomlinson et al., 2010). This technology is currently being used by trained operators, for example UK Plant Health and Seeds Inspectorate (PHSE). It will be interesting to see whether this type of test is taken up by industry for use at grower holdings to evaluate the risk of disease epidemics and the efficacy and timing of control measures.

\section{Molecular Nucleotide Assays:}

Background:

Molecular methods, essentially based upon Polymerase Chain Reaction (PCR), have evolved from a complex highly specialised procedure to become an indispensable, routine tool used widely in the diagnosis of infectious diseases. Over the past two decades PCR and quantitative PCR (q PCR) techniques have expanded to become some of the most widely used laboratory assays for the direct 
measurement of low levels of pathogenic microbes in environmental samples (Theron et al., 2010). The increasing ability to rapidly and economically sequence pathogen genomic content has provided a capability to design specific primer sets to selectively identify nucleotide sequences of fungal and oomycete species.

Nucleotide sequences and sequence databases:

The internal transcribed spacer (ITS) region of ribosomal DNA is reported to be the most widely sequenced DNA region of fungi (Peay et al., 2008). It has been recommended as the universal fungal barcode sequence (Schoch et al., 2012), and as a consequence, has also been adopted for studies of oomycetes (Lévesque, 2011). Consisting of alternating areas of high conservation and variability ITS has proved popular for the development of highly specific and sensitive primer sets for use in PCR based diagnostic tests to discriminate target oomycete plant pathogenic species in complex environmental samples (Klemsdal et al., 2008; Lees et al., 2012). These processes have been successfully applied to develop molecular probes which are able to discriminate and measure many important pathogenic oomycete species in both crops and fish stocks (Beakes et al., 2012; Cooke et al., 2000; Lévesque \& De Cock, 2004; Songe et al., 2015; Tuffs \& Oidtmann, 2011). Other regions of the genome are also of use and have been sequenced to reveal nucleotide base pair differences for the phylogenetic characterisation of Phytophthora and Pythium species. These include the mitochondrial cytochrome oxidase $(\operatorname{cox} 1$ and $\operatorname{cox} 2)$ spacer regions and the nuclear translation elongation factor $1 \alpha$ - and $\beta$-tubulin gene (Kroon et al., 2004; Villa et al., 2006; Blair et al., 2008; Robideau et al., 2011).

Databases exist where DNA sequence data are stored and are available for species comparisons (www.phytophthoradb.org; www.phythophthora-id.org; www.q-bank.eu; www.boldsystems.org), and in some cases these resources provide additional information such as diagnostic morphological features and aspects of biology. Target unidentified organism genomic sequences can readily be compared with database sequences for identification purposes, using DNA-similarity searches like BLAST (Basic Local Alignment Search Tool, Altschul et al., 1997) and DNA and RNA sequence databases, such as the International Nucleotide Sequence Database (INSD). However, caution is still needed in interpreting results of comparisons since for fungal species (bearing in mind that the renamed 'International Code of Nomenclature for algae, fungi and plants' (McNeill et al., 2011) still includes considerations on oomycete nomenclature under 'fungi' with a small ' $\mathrm{f}$ ' (Schroeder et al., 2013)), it has been reported that less than $1 \%$ of the estimated 1.5 million extant species have been sequenced for the ITS region, and that as much as $20 \%$ of all fungal and oomycete sequences deposited in the INSD may be incorrectly annotated to species level (Bridge et al., 2003, Kang et al., 2010, Nilsson et. al., 2006). There are also concerns over the classification of species solely based on results of DNA region/gene analysis. Classical identification of oomycete pathogens for example has relied heavily on morphological and biological features (van der Plaats-Niterink, 1981). These relationships are not always conveyed when compared by genomic 
analysis. Will \& Rubinoff (2004) reported on the myth of the DNA barcode for species classification and reasserted the requirement for morphological analysis in the identification and classification process. Interestingly, in the field of medical mycology the uptake of PCR as a diagnostic tool has been constrained by the lack of standardization, such that PCR is not an accepted diagnostic criterion for the detection of human fungal diseases according to 2008 EORTC/MSG guidelines (De Pauw et al., 2008). Nevertheless, sound oomycete phylogenies are now taking shape, taking morphological and physiological traits into consideration as well as sequence data from a range of regions in addition to ITS (e.g. $\operatorname{cox} 1$ Robideau et al., 2011; or $\beta$ tubulin Villa et al., 2006) and attempts are being made to establish rigorous databases for this information (e.g. The Phytophthora Database: http://www.phytophthoradb.org and The Pythium Genome Database: http://pythium.plantbiology.msu.edu).

\section{PCR assay development}

As with immunoassay systems, consideration should be given to the test sample coverage and the environmental matrix assessed. Extraction and concentration processes may be required for the efficient and reliable amplification of low numbers of target genomic material. Melt and annealing temperatures of the PCR process should be optimised to prevent the formation of undesirable secondary structures such as primer dimers (Saiki et al., 1988; Steffan \& Atlas, 1991). Environmental samples often contain potential assay inhibitors. These may include humic substances, pesticide residues and organic material (Kong et al., 2003). Colloidal matter which has a high affinity for DNA may also be present (Way et al., 1993; Wilson, 1997). The varied occurrence of these in field samples has the potential to disrupt the amplification process and affect test sensitivity (Lombard et al., 2011; Stewart-Wade, 2011).

\section{qPCR:}

qPCR provides a means of measuring the concentration target pathogen DNA, and thus estimating biomass in a sample, by monitoring DNA copy generation using conformational change of fluorescently-labelled probes with reference to a standard curve. This system is often referred to as real-time PCR as the fluorescently-labelled PCR products produced during each amplification cycle can be monitored as the reaction progresses. Where conventional PCR diagnostic testing can be confined by special room requirements to eliminate aerosol contamination (Regis et al., 2006) the 'closed' qPCR process can to some extent overcome this problem. It has also been shown to have advantages of speed, accuracy, and sensitivity over conventional PCR-based techniques (Schaad \& Frederick, 2002). qPCR assays have been widely developed for oomycete pathogens (Cooke et al., 2007; Huang et al., 2010; Kernaghan et al., 2008; Lees et al., 2012; Li et al., 2014; Mulholland et al., 2013; Pavón et al., 2008; Strand et al., 2012; Tuffs \& Oidtmann, 2011).

Unfortunately, the costs of purchasing and installing a 'real time' laboratory operating system are high and with recurrent running costs, currently make this procedure an 
unaffordable option for many laboratories. Nevertheless, where speed, specificity and sensitivity are priorities regardless of cost, analysis by qPCR can prove optimal for test delivery.

Quantitative PCR can also be performed outside of the conventional laboratory setting using a system originally developed for the US military to monitor bioterrorism-related outbreaks of anthrax. For this application the real time platform was supported by a portable battery and packaged in a large brief case to allow rapid field deployment in combat zones. The portable sampler has since been made commercially available (Cepheid Smartcycler Inc., Sunnyvale,California) and has been assessed for its quantitative capability on a small number of human pathogens as well as some 'notifiable' ('Quarantine', IPPC, 2015) plant pathogens (Bélanger et al., 2003; Tomlinson et al., 2005). These systems deploy fully automated sample preparation, using disposable cartridges that accept up to several millilitres of aqueous sample, completing preparation in less than five minutes, and provide limited multiplex detection on a single platform. Despite these developments, the molecular detection of microbial pathogens in plant material and other complex matrices, such as soil or infected animal tissues, is still limited by the need for the pre-extraction of DNA (Healey et al., 2014). For this reason the on-site molecular testing of environmental samples has demanded not only a portable real-time PCR platform but also a simple and robust DNA extraction method. Recent success with field measurements of $P$. ramorum using the nitrocellulose membranes in LFD devices to extract sample DNA (Tomlinson et al., 2010), indicate that perhaps for plant material at least, extraction is not as problematic as previously believed.

\section{Loop-mediated isothermal amplification (LAMP)}

Simpler, less expensive technologies have been sought to allow molecular based assays to be translated from the laboratory to the field. LAMP provides a novel nucleic acid amplification process under isothermal conditions $\left(60\right.$ to $65^{\circ} \mathrm{C}$ ) (Notomi et al., 2000). For this reason simple incubators, such as a water bath or a block heater, are sufficient for DNA amplification. As a by-product of the reaction a white precipitate of magnesium pyrophosphate is produced, which enables the visual judgment of amplification by 'naked eye'. LAMP has been reported to be less affected by inhibitors than other PCR procedures (Francois et al., 2011) and, because of its speed, robustness and simplicity is increasingly used for diagnostics in human medicine (Parida et al., 2008) and, more recently, in plant health (Kubota et al., 2008; Tomlinson et al., 2010; BühImann et al., 2013). In the United States the development of a 'grower performed LAMP PCR' has been assessed for the detection-based management of spray programmes for grapevine powdery mildew in vineyards (Mahaffee et al., 2011; Thiessen et al., 2015). Based on two years of results, a commercial company ran a feasibility trial to offer a grower-based test service. It was estimated that it would require US $\$ 2100$ in capital equipment, US\$60 in reagents and 25 minutes labour with a $1.5 \mathrm{hr}$ process-time for 10 samples. This estimate did not however include the cost of an air sampler for collection of field 
aerosols. The LAMP process consisted of several steps including extraction, heating, and centrifugation, and, although it could be operated in a grower's office with desktop equipment, it was found that participants were not consistently successful when interpreting the results. The company considered performing the LAMP service 'in-house' however opted to partner with a commercial laboratory to offer a laboratory quantitative PCR service (Reiger, 2013). As a result of the high sensitivity of the test, it was observed that one of the biggest concerns in the collection of samples for a commercial DNA-based testing service was the cross-contamination of samples. Spores could be easily picked up and moved on people's clothing and hands. For this reason they instituted clean practices whereby samplers wear gloves and protective clothing, which is changed between traps. Mahaffee and his team at the United States Department of Agriculture continue to work with growers to develop field tests that are more economical and easier to use. They are currently investigating the use of a hand-held, portable device called the Smart-DART (www.diagenetix.com/product-and-technology/smart-dart-platform) which allows the LAMP process to be performed on site and provides an application to an Android phone device for quantitative measurement of the assay process. If this approach is successful, a DNA extraction process will still need to be performed, but costs would be greatly reduced, with estimated complete system set-up costs of less than US $\$ 2000$ in capital equipment and annual operating costs of US $\$ 400$ (Reiger, 2013). This estimate does not include labour costs to operate the system, nevertheless, with appropriate economies of scale, this system could prove useful in a field situations where speed, sensitivity and specificity are key to a successful outcome.

\section{Multiplexing with PCR:}

Where a laboratory/clinic environment is feasible, advances in molecular diagnostic test technology have provided the opportunity to couple PCR with high throughput pathogen detection multiplex arrays. These array systems were originally designed for gene expression profiling, gene discovery and single nucleotide polymorphism (SNP) analysis (Lockhart \& Winzeler 2000; Mei et al., 2000). PCR-based multiplex arrays generally consist of a high density of selected and synthesised immobilized nucleic acid sequences spotted onto a solid platform such as glass microslides, beads or nylon membranes (Eptstein \& Butow, 2000, Ishii et al., 2008). Following DNA extraction from an environmental sample, amplicons of a target DNA region are generated by PCR and bound with a fluorescent, biotinylated or enzyme label. Following a process of DNA hybridisation, amplicons which are able to bind selectively to immobilised target sequences of the array are visualised, either by direct fluorescence scanning or enzyme-mediated detection, to yield a semiquantitative result (de Boer \& Beurmer, 1999). In general, target amplification is based on the use of universal primers that recognize conserved sequences flanking variable domains in housekeeping genes, such as the ribosomal RNA gene. In this way, numerous targets can be amplified with a single primer pair, while target discrimination is performed afterwards on the array (Lievens et al., 2003 \& 2011). 
DNA arrays have been developed for the detection of plant pathogens in a range of environmental samples (Mumford et al., 2006; Boonham et al., 2007; Lievens et al., 2012). For Pythium, a DNA array containing 172 oligonucleotides complementary to specific diagnostic regions of the internal transcribed spacers (ITS) has been developed for the identification and detection of more than 100 species (Tambong et al., 2006). More recently a membrane-based oligonucleotide array has been developed to detect Phytophthora spp by using three DNA regions (ITS, cox1 and cox2-1 spacer). The array was validated with 143 pure cultures and 35 field samples, and showed promising sensitivity, being able to detect as few as $50 \mathrm{pg}$ of PCR amplicon from pure laboratory cultures (Chen et al., 2013). Using a multiplex realtime PCR approach, other workers have reported a detection sensitivity ranging from $1 \mathrm{fg}$ (gene with multiple copies) to $100 \mathrm{fg}$ (single-copy genes) of target Phytophthora DNA (Schena et al., 2006; Tooley et al., 2006). However each of these plant tissue assays was limited to the measurement of a few target species; Phytophthora ramorum, $P$. kernoviae, $P$. citricola and $P$.quercina, in symptomatic leaf samples in the former, and only Phytophthora ramorum and Phytophthora pseudosyringae in the latter test.

As a laboratory tool, the nucleotide-based array system can provide a highly specific and sensitive assay for the simultaneous detection of multiple pathogens present in a cropping system (Robideau et al., 2008) and has also been successfully used to identify species with fungicide resistance (Ishii et al., 2008). In general, macroarrays (immobilized nucleic acid sequences spotted onto reusable membranes) have been used for plant disease diagnosis as a result of cost, sensitivity and the more modest equipment requirements (Lievens et al., 2012). For commercial applications, Bio-art bvba (Belgium) have demonstrated the usefulness of this multiplex approach and report detection of a range of fungal, oomycete and bacterial plant pathogens (DNA MultiScan®, http://www.bio-art.org). Meanwhile, the ongoing, considerable advances in the areas of genomics and bioinformatics mean that ever more powerful molecular diagnostic methodologies continue to be developed. For the oomycetes, sequence data continue to generate and provide additional information for phylogenetic analysis and updating species classifications (Kamoun et al., 2014). Next generation sequencing (NGS) provides the capability to analyse and compare whole genomes of plant pathogens. The Pythium ultimum genome (42.8 Mb) is reported to encode for 15,290 genes of which extensive sequence similarity and synteny with the potato blight pathogen Phytophthora infestans is reported (Lévesque et al., 2010). More recently, analyses on the sequencing, assembly, and annotation of six Pythium genomes ( $P$. aphanidermatum, $P$. arrhenomanes, $P$. irregulare, $P$. ultimum var. sporangiiferum, $P$. vexans and $P$. iwayamai) provides comparison with other plant pathogenic oomycetes including Phytophthora species, Hyaloperonospora arabidopsidis, and Pythium ultimum var. ultimum as well as related animal pathogens such as the important fish pathogen Saprolegnia parasitica (Bishwo et al., 2013). 


\section{Next generation sequencing:}

Next generation sequencing offers a diagnostic tool that requires no previous knowledge of either a specific host or pathogen (Schuster, 2008). It is a highthroughput approach that generates thousands to millions of DNA sequences. However, as a diagnostic technique, obtaining and making sense of these sequences involves several complex stages, both at the lab bench and at the computer desk. With more and more organisms being sequenced, a flood of genetic data is being continually made available (Liu et al., 2012). Distilling meaningful information (bioinformatics) from the millions of new sequences from voluminous, noisy, and often partial sequence data, and interpreting it presents a serious challenge. Analysis requires considerable skill and understanding to avoid potential pitfalls and challenges in the process (Dewoody et al., 2013). Nevertheless, NGS does have the capability to analyse complex environmental samples and from these, identify uncultured known, unknown and novel pathogen variants (Adams et al., 2009, Harju et al., 2012, Bi et al., 2012, Breitbart et al., 2008) and is currently generating very interesting information on the diversity of oomycete species present in disease systems and natural ecosystems (Sapkota \& Nicolaisen, 2015, Vannini et al., 2013). For plant virus identification Adams et al. (2009) reported a cost of $£ 1000$ per sample analysis but that this sum could reduce considerably in the future. However, for the time being NGS is likely to remain a sophisticated laboratory tool, underpinning fundamental genetically-based studies, to provide new perspectives on host-pathogen interactions and ecological studies. It will provide considerable support to the development of new diagnostic, molecular-based technologies.

\section{Practical application of diagnostic tests:}

Tests in the field:

Despite the many exciting developments in diagnostic technologies outlined here, application in the field is still often restricted by the need for (often complex) preprocessing of samples (e.g. nucleic acid extraction), which for environmental samples, especially soil, is still a rate- and skill-limited step (King et al., 2008). Soil can be a particularly challenging environment to work with as texture, structure, $\mathrm{pH}$, electroconductivity and moisture content can vary greatly within a sampling area and considerably influence pathogen distributions. The vertical and horizontal microbial composition will also have an association with the soil tillage, nutrient status and $\mathrm{C}: \mathrm{N}$ ratio (Serrano et al., 2011; Coince et al., 2013; Lindhal et al., 2013).

For on-site testing, ease of use and test reliability are important, but ultimately adoption in agricultural systems will be driven by costs. This situation is a particular consideration for many plant cropping systems where the profit margins and emotional attachment to crops are low. A requirement for skilled staff and expensive equipment with reagents would not be easy to justify. However, as mentioned above, where legislative issues are a factor and potential of quarantine outbreaks a concern, the demand for specificity, sensitivity and speed may to some extent override the 
costs. PCR-based technologies such as LAMP show great promise, and with immunodiagnostic POC tests and NALF technologies seem the most likely to have widespread field application in the short to medium term (Shan, 2011).

\section{Sample volume and sample strategy:}

For agricultural industry use, the focus should be on how the test result will relate to the cropping system. Diagnostic platforms are evolving at a rapid rate and often the material required for analysis reduces as test sensitivity increases. For example, the use of nanotechnology provides potential for small, smart, inexpensive, real-time disposable diagnostic systems with field-portable electronic outputs. However, as the name suggests, nanotechnology will drive even smaller sample volumes. There is a real danger here that test accuracy will be compromised by the restrictive nature of the sample volumes used. This situation could be particularly problematic where disease is present at a sub-clinical level or patchy in large scale cropping systems or in the determination of 'disease-free' status in quarantine, assessments/certification of seed and transplant stock. For a sampling procedure to be effective, the potential spatial and temporal variation of target pathogen incidence within a cropping system need to be evaluated and accommodated by identifying appropriate levels of replication in time and space. Individual mycelia can extend to metres in composite length (Smith et al., 1982; Douhan et al., 2011) and microbial communities can display temporal variation in composition (Bush et al., 2003; Cacciola \& Magnano di San Lio 2008; Courty et al., 2008; Pickles et al., 2010; Davey et al., 2012). This pattern may be short term in response to local weather events (Ristaino, 1991; CaféFilho et al., 1995), or to changes in cultural conditions (Kennedy \& Pegg, 1990), or cyclic in relation to seasons and the phenology of host species (Weste \& Vithanage, 1977; Khallil et al., 1993; Lindhal et al., 2013; Eyre \& Garbelotto, 2015). Sample size and the sampling strategy will be critical factors of an accurate assessment of disease potential (Ranjard et al. 2003). If these hurdles can be overcome, the prospects for widespread uptake of molecular diagnostics within commercial disease management systems are considerable, although, ease of use and cost returns will prove key drivers in their uptake.

\section{Viability of pathogen propagules:}

In some areas of agriculture, the ability to reliably discriminate viable, from dead/inactivated oomycete propagules and the concentrations at which such discrimination might be possible is crucial. This situation is especially true in the testing of recycled water where, following treatments to kill pathogens, many dead pathogen cells and particles of debris can still be present. Differentiating between the infectious (viable) and non-infectious (non-viable) state remains a limitation of PCR (Stewart-Wade, 2011) as DNA persists for significant periods of time after the death of cells (Masters et al., 1994). Vettraino et al. (2010) and Chimento et al. (2012) approached this problem for the detection of Phytophthora cambivora and $P$. ramorum by targeting the mRNA of the cox genes for reverse transcription followed by PCR amplification. As an indicator of viability, mRNA is considered an 
appropriate target since most mRNA species have a short half-life. In bacteria this time amounts to just a few minutes (Kushner 1996), whilst in fungi, the determination of mRNA half-lives for Candida albicans, suggest an enhanced period of between 4$168 \mathrm{~min}$ (Kebaara et al. 2006) and in protists, between 9.5 and $65 \mathrm{~min}$ in Plasmodium falciparum, depending on life-cycle stage (Shock et al., 2007). This potential length of half-life might be reasonable for tests indicating the viability of pathogen inoculum in soil, but is still potentially problematic for tests on the efficacy of water treatments applied to control oomycete pathogens where tests would be applied immediately post treatment and the risk of a high incidence of 'false positive' results could cause unnecessary and expensive disruption. To date, the only truly reliable measures of viable oomycete inoculum remain those that involve a germination step such as conventional agar plating (Büttner et al., 2014), adapted immunodiagnostic dipstick assays (Cahill \& Hardham, 1994) and ZTI (Pettitt et al., 2002).

Uptake of molecular diagnostics within Integrated Disease Management Systems (IDMS):

In contrast to conventional single component control strategies, IDMS aim to combine biological, cultural, physical and chemical strategies in a holistic way (EI Khoury \& Makkouk, 2010). Early pathogen detection, diagnosis and quantitation are central to good crop protection, and successful IDMS depends upon the quality of diagnostic information, its evaluation, and incorporation within the system. For example, once a pathogen is identified, and inoculum concentration data are available, these can be assessed in relation to relevant associated environmental parameters to determine when disease-risk thresholds have been reached (Scherm \& van Bruggen, 1995).

Mathematical plant disease prediction models have been developed and evaluated for a wide range of crop diseases, for example potato blight forecasts (Raposo et al., 1992) and MILIONCAST for Peronospora destructor downy mildew sporulation on onions (Gilles et al., 2004). These can predict optimum times for fungicide application based on meteorological measurements, improving efficacy and often reducing the number of sprays needed for good disease control in comparison to routine spray programmes. This optimisation could be greatly improved by the inclusion of real-time measurements of inoculum. Using slow and highly-skilled microscopic examination of spore trap tapes, measurements of concentrations of airborne sporangia of the potato blight pathogen Phytophthora infestans, demonstrated that peaks of airborne inoculum preceded the first observed symptoms of the disease in the field (Bugiani et al. 1998), whilst in onion downy mildew airborne inoculum must reach high concentrations before crop-to-crop transmission is possible (Gilles et al. 2004). The transmission of airborne pathogens from both within, and outside target crops can be modelled (Deardon et al. 2004; Deardon et al. 2006) and this approach provides scope for the development of regional disease forecasts. Early detection of incoming inoculum can be effectively achieved using 
spore sampling network devices (Skelsey et al. 2009), and such measurements have been used to improve the precision of fungicide decision support systems for potato blight - guiding the timing, and also giving early and precise indications as to the efficacy, of disease management decisions (Fall et al., 2015). More rapid and precise molecular techniques have allowed similar observations in potato blight and other disease systems (Skottrup et al., 2007; Kennedy \& Wakeham 2008; Wakeham \& Kennedy, 2010), readily providing sufficient time for the application of targeted protectant control measures (Wakeham 2014; West \& Kimber, 2015; Thiessen et al. 2015).

As described above, many molecular procedures are best executed under controlled laboratory conditions, possibly providing intelligence to decision support networks. Klosterman (2014) described the coupling of field spore traps and quantitative PCR Assays for detection of the downy mildew pathogens of spinach (Peronospora effusa) and beet ( $P$. schachtii). However, not requiring a pre-extraction or DNA amplification stage, the simplicity, relatively low cost and rapidity of immunological methods makes them an attractive proposition for in-field tests. In the UK, the Brassica Alert network of spore traps provides an inoculum based warning of airborne spore concentrations using lateral flow tests (http://www.syngentacrop.co.uk/brassica-alert). Air samples are only tested when environmental conditions are suitable for Mycospharella brassicicola infection (Wakeham \& Kennedy, 2010). In-field lateral flow tests have also been developed to monitor bioaerosols for the oomycete pathogens Peronospora destructor (onion downy mildew) and Albugo candida (white blister on brassica oleracea) (Kennedy \& Wakeham, 2008; Wakeham 2014). On the other hand, the specificity and sensitivity that can be achieved with molecular DNA-based methods is impressive and real advances have been made towards the deployment of DNA-based systems to the field and in the reduction of analysis cost (Thiessen et al. 2015).

In comparison with airborne disease management, where decision support systems have been widely used for decades, IDMS for soil and water-borne pathogens is less well developed and for many key pathogens, distributions, rates of spread and especially, disease thresholds are still poorly understood. Nevertheless, useful diagnostic assay systems have been developed for a wide range of soil and waterborne pathogens. For example, the rapid and efficient detection of vascular wilt pathogens (Fusarium solani, Rhizoctonia solani, Verticillium species), and Pythium ultimum in plant tissues and irrigation water using DNA array technology (Lievens et al. 2006). In carrot soils, Klemsdal et al. (2008) designed PCR primers for ITS sequences to detect and identify the five most important Pythium species associated with cavity spot in Norway; $P$. intermedium, $P$. sulcatum, $P$. sylvaticum, $P$. violae and $P$. vipa, to provide the possibility of assessing disease risks before deciding whether to crop new fields. The assessment of these disease risks might be enhanced by the use of qPCR (Barbara, 2010), although carrot cavity spot is a complex disease system and research continues at the University of Warwick (UK) to improve assays 
and their interpretation (Clarkson, J., 2016, AHDB project FV391a, personal communication). In commercial Brassica production, qPCR and immunoassay techniques have been compared for their value in IDMS for Plasmodiophora brassicae (clubroot) in soil (Wakeham et al., 2015).

In river and water assessment, significant progress has also been made. Scibetta (2012) described the development and validation of two different rDNA primer sets for assessment of Phythophora species in environmental samples. Using an on-site knapsack system water borne propagules were collected directly from_stream water prior to testing.

Monitoring specific oomycete species is more difficult in soil and water environments than in the air by the common occurrence of mixtures of fairly closely-related species; some pathogenic, many non-pathogenic, and some even mycophagous, with clear biological control potential. Reliable multiplex assays have yet to be developed that allow the monitoring representative Pythium species and their distributions in time and space in soils in relation to both disease occurrence and inter-specific competition/predation, although reasonably effective multiplex assays have been developed that can discern certain key pathogens in soil and water samples (Lievens et al., 2006; Abd-Elmagid et al., 2013). To be truly effective in future IDMS, such assay systems would also need to take the considerable progress made on monitoring biocontrol agents into consideration, for example hyperparasitic species of Trichoderma for which both immunodiagnostic and real-time PCR monitoring procedures have been developed (Thornton et al., 2002; Hagn et al., 2007; Savazzini et al., 2008).

\section{Conclusion}

The increasing concern about pesticides in the environment, removal or restriction of their usage and rising food production costs has focussed the attention towards the improvement of agricultural disease management systems. Early detection allied to key environmental parameters to control disease at the onset can lead to an increase in production, an improvement of resource efficiency and make a substantial contribution to food security. This approach has successfully been applied to measuring the transmission of crop pathogens in bio-aerosols and the timed application of control measures (Wakeham \& Kennedy, 2010, Gent et al, 2013; Fall et al., 2015; West \& Kimber, 2015). In water, growing media and soil progress is hampered by the environmental sample matrix, suitable sampling regimes to reflect the cropping area and target collection efficiency from the sample. Nevertheless, progress with molecular diagnostics of soil and water-borne oomycetes has been rapid over the last decade and there is an array of very promising technologies now beginning to be developed for field use.

The challenge for agricultural scientists however, remains the ability to identify, select and modify available systems to provide diagnostic tools that are able to deliver useful information to the end user. The development of these systems must 
be appropriate to the delivery point, whether it is in a diagnostic laboratory or on-site, whilst remaining mindful of the economies of scale in agribusiness. Once developed, tests must be extensively validated and compared with existing adopted approaches (for example the isolation of pathogens by use of selective media, culture-based morphological analyses and baiting using plant tissues), and that this process is carried out across the range of environments in which the test will be used. If the test is to be carried out by non-scientists, the robustness of the system should be assessed in supported trials with multiple 'non-skilled test' end users. This process will require careful planning with a robust validation period.

\section{References}

Abd-Elmagid A., Garrido P. A., Hunger R., Lyles J.L., Mansfield M.A., Gugino B.K., Smith D.L., Melouk H.A., Garzon C.D. (2013) Discriminatory simplex and multiplex PCR for four species of the genus Sclerotinia. Journal of Microbiological Methods, 92, 293-300.

Adams I.P., Glover R.H., Monger W., Mumford R., Jackeviciene W., Navalinskiene M., Samuitiene M., Boonham N. (2009) Next-generation sequencing and metagenomic analysis: a universal diagnostic tool in plant virology. Molecular Plant Pathology, 10, 537-545.

Ali-Shtayeh M.S., Saleh A.S.F. (1999) Isolation of Pythium acanthicum, $P$.oligandrum and $P$. periplocum from soil and evaluation of their mycoparasitic activity and biocontrol efficacy against selected phytopathogenic Pythium species. Mycopathologia, 145, 143-153.

Altschul S.F., Madden T.L., Schaffer A.A., Zhang J., Zhang Z. (1997) Gapped BLAST and PSI-BLAST: a new generation of protein database search programs. Nucleic Acids Research, 25, 3389-3402.

Arap M.A. (2005) Phage display technology - Applications and innovations. Genetics and Molecular Biology, 28, 1-9.

Arcate J.M., Karp M.A., Nelson E.B. (2006). Diversity of peronosporomycete (oomycete) communities associated with the rhizosphere of different plant species. Microbial Ecology, 51, 36-50.

Bandte M.; Pettitt T.R. (2014) Immunological methods for detection of plant pathogens in irrigation water. In Biology, Detection and Management of Plant Pathogens in Irrigation Water, pp. 149-160. Eds C.X. Hong, G.W. Moorman, W. Wohanka and C. Büttner. St Paul, MN, USA: American Phytopathological Society. 
Barbara D.J. (2010) Carrot cavity spot (i) using quantitative PCR to predict disease in strawed crops; (ii) controlling moisture for optimum disease management. Final Report to HDC FV353. Stoneleigh Park, Warwickshire, UK: AHDB Horticulture.

Barker I., Pitt D. (1988) Detection of the leaf curl pathogen of anemones in corms by enzyme-linked immunosorbent assay (ELISA). Plant Pathology, 37, 417-422.

Barno-Vetro I., Gyongyosi A., Solti L. (1994) Monoclonal antibody-based enzymelinked immunosorbent assay of Fusarium T-2 and zearalenone toxins in cereals. Applied and Environmental Microbiology, 60, 729-731.

Beakes G.W., Glockling S.L., Sekimoto S. (2012) The evolutionary phylogeny of the oomycete 'fungi'. Protoplasma, 249, 3-19.

Bélanger S.D., Boissinot M., Clairoux, N., Picard, F.J., Bergeron M.G. (2003) Rapid Detection of Clostridium difficile in Faeces by Real-Time PCR. Journal of Clinical Microbiology, 41, 730-734.

Bergervoet J.H.W., Peters J., Van Beckhoven J.R.C.M., Van den Bovenkamp G.W., Jacobson J.W., Van der Wolf J.M. (2008) Multiplex microsphere immunodetection of potato virus $\mathrm{Y}, \mathrm{X}$ and PLRV. Journal of Virological Methods. 149, 6368.

Bi J.M., Tugume, A.K., Valkonen J.P. (2012) Small RNA-deep sequencing reveals Arctium tomentosum as a natural host of Alstromeria virus $\mathrm{X}$ and a new putative Emaravirus. DOI: 10.1371/journal.pone.0042758.

Bifulco J.M., Schaefer F.W. (1993) Antibody-magnetic method for selective concentration of Giardia lamblia cysts from water samples. Applied and Environmental. Microbiology, 59, 772-776.

Bishwo N.A., Adhikari J-P., Hamilton M.N., Zerillo N., Tisserat C. A., Levesque A., Buell C.R. (2013) Comparative genomics reveals insight into virulence strategies of plant pathogenic oomycetes. Plos One, 8, e75072.

Blair J.E., Coffey M.D., Park S-Y., Geiser D.M., Kang S. (2008) A multi-locus phylogeny for Phytophthora utilizing markers derived from complete genome sequences. Fungal Genetics and Biology, 45, 266-277.

Boonham N., Tomlinson J., Mumford R. (2007) Microarrays for rapid identification of plant viruses. Annual Review of Phytopathology, 45, 307-28.

Bourke A. (1991) Potato blight in Europe in 1845: the scientific controversy. In Phytophthora, pp. 12-24. Eds J.A. Lucas, R.C. Shattock, D.S. Shaw and L.R. Cooke. Cambridge, UK: Cambridge University Press.

Breitbart M., Haynes M., Kelley S., Angly F., Edwards R.A., Felts B., Mahaffy J.M., Mueller J., Nulton J,.Rayhawk S.,.Rodriguez-Brito B.,.Salamon P.,.Rohwer F. 
(2008) Viral diversity and dynamics in an infant gut. Research in Microbiology, 159, 367-73.

Bridge P.D, Roberts P.J., Spooner B.M., Panchal G. (2003) On the unreliability of published DNA sequences. New Phytologist, 160, 43-48.

Bühlmann A., Pothier J.F., Rezzonico F., Smits T.H.M., Andreou M., Boonham N., Duffy B., Freya J.E. (2013) Erwinia amylovora loop-mediated isothermal amplification (LAMP) assay for rapid pathogen detection and on-site diagnosis of fire blight. Journal of Microbiological Methods, 92, 332-339.

Bugiani, R., Govoni, P., Cobelli, L. (1998) First large scale application of IPI model for potato late blight prediction in the Po valley. Pages 188-199 in: Proc.

Workshop Eur. Network Devel. Integrated Contr. Strat. Potato Late Blight, vol.3 PAV-Spec. Rep. H. Schepers and E. Bouma, eds. Applied Research for Arable Farming and Field Production of Vegetables, Lelystad, Netherlands.

Burger J.T., Von Wechmar M.B. (1988) Rapid diagnosis of Ornithogalum and Lachenalia viruses in propagation stock. Acta Horticulturae, 234, 31-38.

Bush E.A., Hong C.X., Stromberg E.L. (2003) Fluctuations of Phytophthora and Pythium spp. in components of a recycling irrigation system. Plant Disease 87:1500-1506.

Büttner C.,Bandte M., Pettitt T.R. (2014) Filtration and centrifugation for detection of plant pathogens in irrigation water. In Biology, Detection and Management of Plant Pathogens in Irrigation Water, pp. 139-148. Eds C.X. Hong, G.W. Moorman, W. Wohanka and C. Büttner. St Paul, MN, USA: American Phytopathological Society.

Cacciola, S.O., Magnano di San Lio, G. (2008). Management of citrus diseases caused by Phytophthora spp. In Integrated management of diseases caused by fungi, phytoplasma and bacteria, pp. 61-84. Eds A.Ciancio, K.G. Mukerjii. Berlin, Germany: Springer Science \& Business Media BV.

Café-Filho A.C., Duniway J.M., Davis R.M. (1995) Effects of the frequency of furrow irrigation on root and fruit rots of squash caused by Phytophthora capsici. Plant Disease 79:44-48.

Cahill D.M., Hardham A.R. (1994) Exploitation of zoospore taxis in the development of a novel dipstick immunoassay for the specific detection of Phytophthora cinnamomi. Phytopathology, 84, 193-200.

Casale W.L., Pestka J.J., Hart L.P. (1988) Enzyme-linked immunosorbent assay employing monoclonal antibody specific for deoxynivalenol (vomitoxin) and several analogs. Journal of Agriculture Food Chemistry, 36, 663-668. 
Casper R., Mendgen K. (1979) Quantitative serological estimation of a hyperparasite: detection of Verticillium lecanii in yellow rust infected wheat leaves by ELISA. Phytopathologische. Zeitschrift, 94, 89-91.

Charlermroj R., Himananto O., Seepiban C., Kumpoosiri M., Warin N., Oplatowska M., Gajanandana O., Grant I.R., Karoonuthaisiri N., Elliott C.T. (2013) Multiplex detection of plant pathogens using a microsphere immunoassay technology. DOI: 10.1371/journal.pone.0062344 (Open Access).

Chen W., Robleh Djama Z., Coffey M.D., Martin F.N., Bilodeau G.J., Radmer L., Denton G., Lévesque C.A. (2013) Membrane-based oligonucleotide array developed from multiple markers for the detection of many Phytophthora species. Phytopathology, 103, 43-54.

Chimento A., Cacciola S.O., Garbelotto M. (2012) Detection of mRNA by reversetranscription PCR as an indicator of viability in Phytophthora ramorum. Forest Pathology, 42, 14-21.

Clark M.F., Adams A.N. (1977) Characteristics of the microplate method of enzymelinked immunosorbent assay for the detection of plant viruses. Journal of General Virology, 34, 475-83.

Coince A., Caël O., Bach C., Lengellé J., Cruaud C., Gavory F., Morin E., Murat C., Marçais B., Buée M. (2013) Below-ground fine-scale distribution and soil versus fine root detection of fungal and soil oomycete communities in a French beech forest. Fungal Ecology 6:223-235.

Collins S., McComb J.A., Howard K., Shearer B.L., Colquhoun I.J., Hardy G.E.StJ. (2012) The long term survival of Phytophthora cinnamomi in mature Banksia grandis killed by the pathogen. Forest Pathology, 42, 28-36.

Cooke D.E.L., Drenth A., Duncan J.M., Wagels G., Brasier C.M. (2000) A molecular Phylogeny of Phytophthora and related oomycetes. Fungal Genetics and Biology, 30, 17-32.

Cooke D.E.L., Schena L., Cacciola S.O. (2007) Tools to detect, identify and monitor Phytophthora species in natural ecosystems. Journal of Plant Pathology, 89, 1328.

Cook R.J., Veseth R.J. (1991) Wheat health management. St Paul, MN, USA: American Phytopathological Society Press.

Courty P-E, Franc A, Garbaye J. 2008. Temporal changes in the ecotomycorrhizal community in two soil horizons of a temperate oak forest. Applied and Environmental Microbiology, 74, 5792-5801.

Cullen D.W., Toth I.K., Boonham N., Walsh K., Barker I., Lees A.K. (2007) Development and validation of conventional and quantitative polymerase chain 
reaction assays for detection of storage rot potato pathogens, Phytophthora erythroseptica, Pythium ultimum and Phoma foveata. Journal of Phytopathology, 155, 309-315.

Da Silva Bahia M.C.F., Haido R.M.T., Figueiredo M.H.G., Dos Santos G.P.L., Bezerra L.M.L., Hearn V.M., Barreto-Bergter E. (2003) Humoral immune response in aspergillosis: an immunodominant glycoprotein of $35 \mathrm{kDa}$ from Aspergillus flavus. Current. Microbiology, 47, 163-168.

Davey, M.L., Heegaard, E., Halvorsen R., Ohlson, M. Kauserud H. 2012. Seasonal trends in the biomass and structure of bryophyte-associated fungal communities explored by 454 pyrosequencing. New Phytologist 195, 844-856.

Deardon R., Gilmore S.G., Butler N.A., Phelps K., Kennedy R. (2004) A method for ascertaining and controlling representation bias in field trials for airborne pathogens. Journal of Applied Statistics 31:329-343.

Deardon R., Gilmore S.G., Butler N.A., Phelps K., Kennedy R. (2006) Designing field experiments which are subject to representation bias. Journal of Applied Statistics 33:663-678.

De Boer E., Beumer R.R. (1999) Methodology for detection and typing of foodborne microorganisms. International Journal of Food Microbiology, 50, 119-130.

De Pauw B., Walsh T.J., Donnelly J.P., Stevens D.A., Edwards J.E., Calandra T., Pappas P.G., Maertens J., Lortholary O., Kauffman C.A., Denning D.W., Patterson T.F., Maschmeyer G., Bille J., Dismukes W.E., Herbrecht R., Hope W.W., Kibbler C.C., Kullberg B.J., Marr K.A., Muñoz P., Odds F.C., Perfect J.R., Restrepo A., Ruhnke M., Segal B.H., Sobel J.D., Sorrell T.C., Viscoli C., Wingard J.R., Zaoutis T., Bennett J.E. (2008) Revised definitions of invasive fungal disease from the European Organization for Research and Treatment of Cancer/Invasive Fungal Infections Cooperative Group and the National Institute of Allergy and Infectious Diseases Mycoses Study Group (EORTC/MSG) Consensus Group. Clinical Infectious Diseases, 46, 1813-1821.

De Saeger S., Van Peteghem C. (1996) Dipstick enzyme immunoassay to detect Fusarium T-2 toxin in wheat. Applied and Environmental Microbiology, 62, 18801884.

Dewey F.M., Banham A.H., Priestley R.A., Martin B., Hawes C., Phillips S.I., Wareing P.W. (1993) Monoclonal antibodies for the detection of spoilage fungi. International Biodeterioration and Biodegradation, 32, 127-136.

Dewey F.M., Grant-Downton R. (2016) Botrytis-Biology, Detection and Quantification. In Botrytis - the Fungus, the Pathogen and its Management in Agricultural Systems, pp. 17-34. Eds S. Fillinger and Y. Elad. Switzerland: Springer International. 
Dewey F.M., Hill M., De Scenzo R. (2008) Quantification of Botrytis and Laccase in Wine grapes. American Journal of Enology and Viticulture,.59, 47-54.

Dewey F.M., MacDonald M.M., Phillips S.I., Priestley R.A. (1990) Development of monoclonal-antibody-ELISA and DIP-STICK immunoassays for Penicillium islandicum in rice grains. Journal of General. Microbiology, 136, 753-760.

Dewey F.M, Steel C.C. Gurr, S.J. (2013) Lateral-flow devices to rapidly determine levels of stable botrytis antigens in table and dessert wines. American Journal of Enology and Viticulture, 64, 291-295.

Dewey F.M. Thornton C.R. (1995) New diagnostics in crop sciences: Fungal immunodiagnosis in plant agriculture. Biotechnology in Agriculture, 13,151-170.

Dewey F.M., Thornton C.R., Gilligan C.A. (1997) Use of Monoclonal Antibodies to Detect, Quantify and Visualize Fungi in Soils. Advances in Botanical Research, 24, 275-308.

Dewey F.M., Yohalem D. (2007) Detection, quantification and immunolocalisation of Botrytis species. In Botrytis: Biology, Pathology and Control, pp. 181-194. Eds Y. Elad, B. Williamson, P. Tudzynski and N. Delen. Dordrecht, The Netherlands: Springer.

Dewoody R.S., Merritt P.M., Marketon M.M. (2013) Regulation of the Yersinia type III secretion system: traffic control. Frontiers in Cellular and Infection Microbiology, 3, 4, DOI:10.3389/fcimb.2013.00004.

Dhingra O.D., Sinclaire J.B. (1995) Basic plant pathology methods. Boca Raton, FL, USA: CRC Lewis Publishers.

Douhan G.W., Vincent L., Gryta H., Selosse, M.A. 2011. Population genetics of ectomycorrhizal fungi: from current knowledge to emerging directions. Fungal Biology 1155, 569-597.

Drouhet E. (1986) Overview of fungal antigens. In Fungal Antigens, Isolation, Purification and Detection, pp. 3-38. Eds E. Drouhet, G.T. Cole, L. de Repentigny, J-P. Latge and B. Dupont. New York, USA: Plenum Press.

El Khoury W., Makkouk K. (2010) Integrated plant disease management in developing countries. Journal of Plant Pathology, 92, S4.35-S4.42.

Ellis M.A., Miller S.A. (1993) Using a Phytophthora-specific immunoassay kit to diagnose raspberry Phytophthora root rot. HortScience, 28, 642-644.

Epstein C.B., Butow R.A. (2000) Microarray technology - enhanced versatility, persistant challenge. Current Opinion in Biotechnology, 11, 36-41. 
Estrada-Garcia T.M., Callow J.A., Green J.R. (1990) Monoclonal antibodies to the adhesive cell coat secreted by Pythium aphanidermatum zoospores recognise $200 \times 10^{3} \mathrm{M}_{\mathrm{r}}$ glycoproteins stored within large peripheral vesicles. Journal of Cell Science, 95,199-206.

Eyre C.A., Garbelotto M. (2015) Detection, diversity, and population dynamics of waterborne Phytophthora ramorum populations. Phytopathology 105:57-68.

Fall M.L., Van der Heyden H., Brodeur L., Leclerc Y., Moreau G. and Carisse O. (2015) Spatiotemporal variation in airborne sporangia of Phytophthora infestans:characterisation and initiatives towards improving potato late blight risk estimation. Plant Pathology, 64, 178-190. doi:1111/ppa.12235.

Fang Y., Ramasamy R.P. (2015) Review Current and Prospective Methods for Plant Disease Detection. Biosensors 4, 537-561. doi:10.3390/bios5030537.

Fox R.T.V. (1993) Principles of diagnostic techniques in plant pathology. Wallingford, UK: CAB International.

Francois P., Tangomo M., Hibbs J., Bonetti E-J., Boehme C.C., Notomi T., Perkins M.D., Schrenzel J. (2011) Robustness of a loop-mediated isothermal amplication reaction for diagnostic applications. FEMS Immunology and Medical Microbiology, 62, 41-48.

Gent, D.H., Mahaffee, W.F., McRoberts, N., Pfender, W.F. (2013). The use and role of predictive systems in disease management. Phytopathology, 51, 267-289.

Gilles T., Clarkson J.P., Phelps K. and Kennedy R. 2004. Development of MILIONCAST, an improved model for predicting downy mildew sporulation on onions. Plant Disease, 88, 695-702.

Guehi S.T., Dingkuhn M., Cros E., Fourny G., Ratomahenina R., Moulin G., Vidal A.C. (2008) Impact of cocoa processing technologies in free fatty acids formation in stored raw cocoa beans. African Journal of Agricultural Research, 3, 174-179.

Hagn A., Wallisch S., Radl V., Munch J.C., Schloter M. (2007) A new cultivation independent approach to detect and monitor common Trichoderma species in soils. Journal of Microbiological Methods 69:86-92.

Hardham A.R., Suzaki E., Perkin J.L. (1986) Monoclonal antibodies to isolate, species and genus-specific components on the surface of zoospores and cysts of the fungus Phytophthora cinnamomi. Canadian Journal of Microbiology, 36, 183192.

Harlow E., Lane D. (1988) Antibodies A laboratory manual. New York, USA: Cold Spring Harbor Laboratory. 
Harju V., Skelton A., Forde S., Bennett S., Glover R.H., Monger W.A., Adams I.P., Boonham N., Fox A. (2012) New virus detected on Nasturtium officinale (watercress). BSPP New Disease Reports, 25, DOl:org/10.5197/j.2044-

0588.2012.025.001.

Healey A., Furtado A., Cooper T., Henry R.J. (2014) Protocol: a simple method for extracting next-generation sequencing quality genomic DNA from recalcitrant plant species. Plant Methods 2014 10:21, DOI:10.1186/1746-4811-10-21.

Hiltunen L.H., White J.G. (2002) Cavity spot of carrot (Daucus carota). Annals of Applied Biology, 141, 201-223.

Hong C., Richardson P.A., Kong P. (2002) Comparison of Membrane Filters as a Tool for Isolating Pythiaceous Species from Irrigation Water. Phytopathology, 92, 610-616.

Huang J., Wu J., Li C., Xiao C., Wang G. (2010) Detection of Phytophthora nicotianae in soil with real-time quantitative PCR. Journal of Phytopathology, 158, 15-21.

Hüberli D., Tommerup I.C., Hardy G.E.St.J. (2000) False-negative isolations or absence of lesions may cause mis-diagnosis of diseased plants infected with Phytophthora cinnamomi. Australasian Plant Pathology, 29, 164-169.

IPPC (2015) Glossary of Phytosanitary Terms. International Standards for Phytosanitory Measures ISPM 5. Rome, Italy: International Plant Protection Convention, Food and Agriculture Organisation of the United Nations.

Ishii S., Shimoyama T., Hotta Y., Watanabe K. (2008) Characterization of a filamentous biofilm community established in a cellulose-fed microbial fuel cell. BMC Microbiology, 8, 6. DOI:10.1186/1471-2180-8-6 12p.

Jeong-Yeol Y., Bumsang K. (2012) Lab-on-a-Chip Pathogen Sensors for Food Safety. Sensors.12, 10713-10741.

Johne B., Jarp J., Haaheim L. R. (1989) Staphylococcus aureus exopolysaccharide in vivo demonstrated by immunomagnetic separation and electron microscopy. Journal of Clinical Microbiology, 27, 1631-1635.

Johnson M.C., Pirone T.P., Siegel M.R., Varney D.R. (1982) Detection of Epichloe typhina in tall fescue by means of enzyme-linked immunosorbent assay. Phytopathology, 72, 647-650.

Kageyama K., Kobayashi M., Tomita M., Kubota N., Suga H., Hyakumachi M. (2002) Production and Evaluation of Monoclonal Antibodies for the Detection of Pythium sulcatum in Soil. Phytopathology, 150, 97-104. 
Kamoun S., Furzer O, Jones J.D.G., Judelson H.S., Ali G.S., Dalio R.J.D., Roy S.G., Schena L., Zambounis A., Panabières F., Cahill D., Ruocco M., Figueiredo A., Chen X-R., Hulvey J., Stam R., Lamour K., Gijzen M., Tyler B.M., Grünwald N.J., Mukhtar M.S., Tomé D.F.A., Tör M., Van den Ackerveken G., McDowell J., Daayf F., Fry W.E., Lindqvist-Kreuze H., Meijer H.J.G., Petre B., Ristaino J., Yoshida K., Birch P.R.J., Govers F. (2014) The top 10 oomycete pathogens in molecular plant pathology. Molecular Plant Pathology, 16, 413-434.

Kang S., Mansfield M. A., Park B., Geiser D. M., Ivors K. L., Coffey M. D., Grünwald N. J., Martin F. N., Lévesque C. A., Blair J. E. (2010) The promise and pitfalls of sequence-based identification of plant pathogenic fungi and oomycetes.

Phytopathology, 100, 732-737.

Karpovich-Tate N., Spanu P., Dewey F.M. (1998) Use of monoclonal antibodies to determine biomass of Cladosporium fulvum in infected tomato leaves. Molecular Plant-Microbe Interactions, 11, 710-716.

Kebaara, B.W., Nielsen, L.E., Nickerson, K.W., Atkin, A.L. (2006). Determination of mRNA half-lives in Candida albicans using thiolutin as a transcription inhibitor. Genome 49:894-899

Keen N.T., Legrand M. (1980) Surface glycoproteins. Evidence that they may function as the race specific phytoalexin elicitors of Phytophthora megasperma sp. glycinea. Physiological Plant Pathology, 17, 175-192.

Kemeny, D.M. (1991). A practical guide to ELISA. Oxford, UK: Pergamon Press.

Kennedy R., Pegg G.F. (1990) Phytophthora cryptogea root rot of tomato in rockwool nutrient culture. II. Effect of root zone temperature on infection, sporulation and symptom development. Annals of Applied Biology 117:537-551.

Kennedy R., Wakeham A.J. (2008) Development of detection systems for the sporangia of Peronospora destructor. European Journal of Plant Pathology 122:147-155.

Kennedy R., Wakeham A. (2013) Brassicas: Further development of 'in field' tests for resting spores of clubroot and the development of clubroot control based on detection. Final Report to HDC FV349. Stoneleigh Park, Warwickshire, UK: AHDB Horticulture.

Kenny S.R., White J.G., Walker A. (2001) Evidence for the enhanced degradation of metalaxyl in UK carrot soils. BCPC Symposium Proceedings No. 78: Pesticide Behaviour in Soils and Water. Pp. 133-138.

Kernaghan G., Reeleder R.D., Hoke S.M.T. (2008) Quantification of Pythium populations in ginseng soils by culture dependent and real-time PCR methods. Applied Soil Ecology, 40, 447-455. 
Khallil A.M., El-Hissy F.T., Abdel-Raheem A. (1993) Monthly variations of Oomycetes (zoosporic fungi) and aquatic Hyphomycetes at Sohag (Upper Egypt). Acta Societatis Botanicorum Poloniae 62, 67-73.

Kim S.J., Taitt C.R., Ligler F.S. (2010) Multiplexed magnetic microsphere immunoassays for detection of pathogens in foods. Sensing and Instrumentation for Food Quality and Safety, 4, 73-81.

King D.P., Dukes J.P., Reid S.M., Ebert K., Shaw A.E., Mills C.E., Boswell L., Ferris N.P. (2008) Prospects for rapid diagnosis of foot-and-mouth disease in the field using RT-PCR. Vetinary Record, 162, 315-316.

Klemsdal S.S., Herrero M.L., Wanner L.A., Lund G., Hermansen A. (2008) PCRbased identification of Pythium spp. causing cavity spot in carrots and sensitive detection in soil samples. Plant Pathology. 57, 877-886.

Klosterman SJ., Anchieta A., McRoberts N., Koike S.., Subbarao K.V., Voglmayr H., Choi Y.J., Thines M., Martin F.N. (2014). Coupling spore traps and quantitative PCR assays for detection of the downy mildew pathogens of spinach (Peronospora effusa) and beet (P. schachti). Phytopathology, 104, 1349-1359

Köhler G., Milstein C. (1975) Continuous cultures of fused cells secreting antibody of predefined specificity. Nature, 256, 495-497.

Kong P., Hong C.X., Richardson P.A. (2003) Rapid detection of Phytophthora cinnamomi using PCR with primers derived from the $L p v$ putative storage protein genes. Plant Pathology, 52, 681-693.

Kox L.F.F., van Brouwershaven I.R., van de Vossenberg B.T.L.H., van den Beld H.E., Bonants P.J.M., de Gruyter J. (2007) Diagnostic values and utility of immunological, morphological, and molecular methods for in planta detection of Phytophthora ramorum. Phytopathology, 97, 1119-1129.

Kroon L.P.N.M., Bakker F.T., van den Bosch G.B.M., Bonnants P.J.M., Flier W.G. (2004) Phylogenetic analysis of Phytophthora species based on mitochondrial and nuclear DNA sequences. Fungal Genetics and Biology, 41, 766-782.

Kubota R., Vine B.G., Alvarez A.M., Jenkins D.M. (2008) Detection of Ralstonia solanacearum by loop-mediated isothermal amplification. Phytopathology, 98, 1045-1051.

Kushner S.R. (1996) mRNA decay. In Escherichia coli and Salmonella Cellular and Molecular Biology, pp. 849-860. Ed F.C. Neidhardt. Washington, USA: ASM Press.

Lane C.R., Hobden E., Walker L., Barton V.C., Inman A.J., Hughes K.J.D., Swan H., Colyer A., Barker I. (2007) Evaluation of a rapid diagnostic field test kit for 
identification of species, including Phytophthora ramorum and P. kernoviae at the point of inspection. Plant Pathology, 56, 828-835.

Larroque M., Belmas E., Martinez T., Vergnes S., Ladouce N., Lafitte C., Gaulin E., Dumas, B. (2013) Pathogen-associated molecular pattern-triggered immunity and resistance to the root pathogen Phytophthora parasitica in Arabidopsis. Journal of Experimental Botany, 64, 3615-3625.

Lees A.K., Sullivan L., Lynott J.S., Cullen D.W. (2012) Development of a quantitative real-time PCR assay for Phytophthora infestans and its applicability to leaf, tuber and soil samples. Plant Pathology, 61, 867-876.

Lévesque C.A. (2011) Fifty years of oomycetes - from consolidation to evolutionary and genomic exploration. Fungal Diversity, 50, 35-46.

Lévesque A., Brouwer H., Cano L., Hamilton J.P., Holt C., Huitema E., Raffaele S., Robideau G.P., Thines M., Win J., Zerillo M.M., Beakes G.W., Boore J.L., Busam D., Dumas B., Ferriera S., Fuerstenberg S.I., Gachon C.M.M., Gaulin E., Govers F., Grenville-Briggs L., Horner N., Hostetler J., Jiang R.H.Y., Johnson J., Krajaejun T., Lin H., Meijer H.J.G., Moore B., Morris P., Phuntmart V., Puiu D., Shetty J., Stajich J.E., Tripathy S., Wawra S., van West P., Whitty B.R., Coutinho P.M., Henrissat B., Martin F., Thomas P.D., Tyler B.M., De Vries R.P., Kamoun S., Yandell M., Tisserat N., Buell C.R. (2010) Genome sequence of the necrotrophic plant pathogen Pythium ultimum reveals original pathogenicity mechanisms and effector repertoire. Genome Biology, 11, R73 http://genomebiology.com/2010/11/7/R73 22p.

Lévesque C.A., DeCock A.W.A.M. (2004) Molecular phylogeny and taxonomy of the genus Pythium. Mycological Research, 108, 1363-1383.

Lewis M.C. (2011) The development of assays to determine the effect of environmental factors on the viability of Plasmodiophora brassicae resting spores. $\mathrm{PhD}$ thesis, University of Warwick, UK.

Li M., Ishiguro Y., Otsubo K., Suzuki H., Tsuji T., Miyake N., Nagai H., Suga H., Kageyama K. (2014) Monitoring by real-time PCR of three water-borne zoosporic Pythium species in potted flower and tomato greenhouses under hydroponic culture systems. European Journal of Plant Pathology, 140, 229-242.

Lievens B., Brouwer M., Vanachter A.C.R.C., Cammue B.P.A., Thomma B.P.H.J. (2006) Real-time PCR for detection and quantification of fungal and oomycete tomato pathogens in plant and soil samples. Plant Science, 171, 155-165.

Lievens B., Brouwer M., Vanachter A.C.R.C., Lévesque C.A., Cammue B.P.A., Thomma B.P.H.J. (2003) Design and development of a DNA array for rapid detection and identification of multiple tomato vascular wilt pathogens. FEMS Microbiology Letters, 223, 113-122. 
Lievens B., Frans I., Heusdens C., Justé A., Jonstrup S.P., Lieffrig F., Willems K.A. (2011) Rapid detection and identification of viral and bacterial fish pathogens using a DNA array-based multiplex assay. Journal of Fish Diseases, 34, 861-875.

Lievens B., Justé A., Willems K.A. (2012) Fungal Plant Pathogen Detection in Plant and Soil Samples Using DNA Macroarrays. Methods in Molecular Biology, 835, 491-507.

Lindhal, B.D., Nilsson, R.H., Tedersoo, L., Abarenkov, K., Carlsen, T., Rasmus, K., Koljalg, U., Pennanen, T., Rosendahl, S., Stenlid, J., Kauserud, H. (2013) Fungal community analysis by high-throughput sequencing of amplified markers - a user's guide. New Phytologist, 199:288-299.

Liu L., Li Y., Li S., Hu N., He Y., Pong R., Lin D., Lu L., Law M. (2012) Comparison of next-generation sequencing systems. Journal of Biomedicine and Biotechnology 2012, Article ID 251364, DOI: 10.1155/2012/251364 (Open Access). 11p.

Lockhart D.J., Winzeler E.A. (2000) Genomics, gene expression and DNA arrays. Nature,.405, 827-836.

Lombard N., Prestat E., van Elsas J.D., Simonet P. (2011) Soil-specific limitations for access and analysis of soil microbial communities by metagenomics. FEMS Microbiological Ecology, 78, 31-49.

Luk J.M.C., Lindberg A.A. (1991) Rapid and sensitive detection of Salmonella by immunomagnetic monoclonal antibody-based assays. Journal of. Immunological. Methods, 137, 1-8.

Lyons N.F., White J.G. (1992) Detection of Pythium violae and Pythium sulcatum in carrots with cavity spot using competition ELISA. Annals of Applied Biology, 120, 235-244.

Mahaffee W.F., Grove G.G., Stole R. (2011) Inoculum detection to manage grape powdery mildew. Practical Winery and Viticulture, Spring 2011, 26-32

Mansfield L.P., Forsythe S.J. (1993) Immunomagnetic separation as an alternative to enrichment broths for Salmonella detection. Letters in. Applied. Microbiology, 16, 122-125.

Maragos C.M., Busman M., Plattner R.D. (2008) Development of monoclonal antibodies for the fusarin mycotoxins. Food Additives and Contaminants. Part $A$ Chemistry, Analysis, Control, Exposure, Risk Assessment, 25, 105-114.

Martin F.N., Hancock J.G. (1987) The use of Pythium oligandrum for biological control of preemergence damping off caused by $P$. ultimum. Phytopathology, 77, 1013-1020. 
Masters C.I., Shallcross J.A., Mackey B.M. (1994). Effect of stress treatments on the detection of Listeria monocytogenes and enterotoxigenic Escherichia coli by the polymerase chain reaction. J. Appl. Bacteriol. 77, 73 - 79.

McNeill J., Turland N.J., Monro A.M., Lepschi B.J. (2011) XVIII International Botanical Congress: Preliminary mail vote and report of Congress action on nomenclature proposals. Taxon, 60, 1507-1520.

Mei R., Lockhart D.J., Galipeau P.C., Prass C., Berno A., Ghandour G., Patil N., Wolff R.K., Chee M.S., Reid B.J. (2000). Genome-wide detection of allelic imbalance using human SNPs and high-density DNA arrays. Genome Research, 10, 1126-1137.

Mendgen K. (1986). Quantitative serological estimations of fungal colonization. In Microbiology of the Phyllosphere, pp. 50-59. Eds N.J. Fokkema and J. van den Heuvel. Cambridge, UK: Cambridge University Press.

Miller S.A., Madden L.V., Schmitthenner A.F. (1997) Distribution of Phytophthora spp. in Field Soils determined by Immunoassay. Phytopathology, 87, 101-107.

Miller S.A., Rittenburg J.H., Petersen F.P., Grothaus G.D. (1990) Development of modem diagnostic tests and benefits to the fanner. In Monoclinal antibodies in agriculture, pp. 15-20. Ed H. Schots. Wageningen, The Netherlands. Center for Agricultural Publishing and Documentation.

Mohan S.B. (1989a) Analysis of cross-reactive antigens of Phytophthora fragariae and strawberry and their reaction to a resistance and susceptibility. Journal of Phytopathology, 127, 316-330.

Mohan S.B. (1989b) Cross-reactivity of antiserum raised against Phytophthora fragariae with other Phytophthora species and its evaluation as a genus-detecting antiserum. Plant Pathology, 38, 352-363.

Mulholland V., Schlenzig A., MacAskill G.A., Green S. (2013) Development of a quantitative real-time PCR assay for the detection of Phytophthora austrocedrae, an emerging pathogen in Britain. Forest Pathology, 43, 513-517.

Mullins P.H., Gürtler H., Wellington E.M.H. (1995) Selective recovery of Streptosporangium fragile from soil by indirect immunomagnetic capture. Microbiology, 141, 2149-2156.

Mumford R., Boonham N., Tomlinson J.A., Barker I. (2006) Advances in molecular phytodiagnostics - new solutions for old problems. European Journal of Plant Pathology, 116, 1-19. 
Nicolaisen M., Justesen A.F. (2007) Rapid determination of Phytophthora infestans sporangia using a surface plasmon resonance immunosensor. Journal of Microbiological Methods 68, 507-515.

Nilsson R.H., Ryberg M., Kristiansson R., Abarenkov K., Larsson K.H., Koljalg U. (2006) Taxonomic reliability of DNA sequences in public sequence databases: A fungal perspective. PLOS ONE DOI:10.1371/journal.pone.0000059.

Nome S.F., Raju B.C., Goheen A.C., Nyland G., Docampo D. (1980) Enzyme-linked immunosorbent assay for Pierce's disease bacteria in plant tissues. Phytopathology, 70, 746-749.

Notermans S., Soentoro P.S. (1986) Immunological relationship of extracellular polysaccharide antigens produced by different mould species. Journal of Microbiology, 52, 393-401.

Notomi T., Okayama H., Masubuchi H., Yonekawa T., Watanabe K., Amino N., Hase T. (2000) Loop-mediated isothermal amplification of DNA. Nucleic Acids Research, 28, 12,e63. DOI: 10.1093/nar/28.12.e63 (Open Access).

Otten W., Gilligan C.A., Thornton C.R. (1997) Quantification of fungal antigens in soil with a monoclonal antibody-based ELISA: Analysis and Reduction of Soil-Specific Bias. Phytopathology, 87, 730-736.

Ozcan A. (2014) Mobile phones democratize and cultivate next-generation imaging, diagnostics and measurement tools. Lab on a Chip, DOI: 10.1039/c4lc00010b.

Papavizas G.C., Ayers W.A. (1974) Aphanomyces species and their root diseases in pea and sugar beet: A review. Agricultural Research Service, USDA, Technical Bulletin, 1485, 158p.

Parida M., Sannarangaiah S., Kumar Dash P., Rao P.V L., Morita K. (2008) Loop mediated isothermal amplification (LAMP): a new generation of innovative gene amplification technique; perspectives in clinical diagnosis of infectious diseases. Review of Medical Virology, 18, 407-421.

Paulitz T.C., Ahmad J.S., Baker R. (1990) Integration of Pythium nunn and Trichoderma harzianum isolate T-95 for the biological control of Pythium dampingoff of cucumber. Plant and Soil, 121, 243-250.

Pavón C.F., Babadoost M., Lambert K.N. (2008) Quantification of Phytophthora capsici oospores in soil by sieving-centrifugation and real-time polymerase chain reaction. Plant Disease, 92, 143-149.

Peay K.G., Kennedy P.G., Bruns T.D. (2008) Fungal community ecology: a hybrid beast with a molecular master. BioScience, 58, 799-810. 
Pettitt T.R., Finlay A.R., Scott M.A., Davies E.M. (1998) Development of a system simulating commercial production conditions for assessing the potential spread of Phytophthora cryptogea root rot of hardy nursery stock in recirculating irrigation water. Annals of Applied Biology, 132, 61-75.

Pettitt T.R., Pegg G.F. (1991) The quantitative estimation of Phytophthora cactorum in infected strawberry tissue. Mycological Research, 95, 233-238.

Pettitt T.R., Pegg G.F. (1994) Sources of crown rot infection (Phytophthora cactorum) in strawberry and the effect of cold storage on susceptibility to the disease. Annals of Applied Biology, 125, 279-292.

Pettitt TR, Wakeham AJ, Wainwright MF, White JG. (2002) Comparison of serological, culture, and bait methods for detection of Pythium and Phytophthora zoospores in water. Plant Pathology, 51, 720-727.

Phelps K., White J.G., Henn A.J. (1991) Studies on the spatial distribution of Pythium-induced cavity spot of carrots. Annals of Applied Biology, 119, 21-30.

Pickles B.J., Genney D.R., Potts J.M., Lennon J.J., Anderson I.C. Alexander I.J. (2010). Spatial and temporal ecology of Scots pin ectomycorrhizas. New Phytologist, 186, 755-768.

Pittis J.E., Colhoun J. (1984) Isolation and identification of Pythiaceous fungi from irrigation water and their pathogenicity to Antirrhinum, tomato and Chamaecyparis lawsoniana. Phytopathologische Zeitschrift, 110, 301-318.

Posthuma-Trumpie G.A., Amerongen A.V., Korf J., Van Berkel W.J.H. (2009) Perspectives for on-site monitoring of progesterone. Trends in Biotechnology, 27, 652- 660.

Priestley R.A., Dewey F.M. (1993) Development of a monoclonal antibody immunoassay for the eyespot pathogen Pseudocercosporella herpotrichoides. Plant Pathology, 42,403-412.

Raju B.C., Olson C.J. (1985) Indexing systems for producing clean stock for disease control in commercial floriculture. Plant Disease, 69,189-192.

Ranjard L., Lejoin D.P.H, Mougel C., Scherhrer L., Merdinoglu D., Chaussod R. (2003) Sampling strategies in molecular microbial ecology: Influence of soil sample DNA fingerprinting analysis of fungal and bacterial communities. Environmental Microbiology, 5,1111-1120.

Raposo R., Wilks D.S., Fry W.E. (1992). Evaluation of Potato late blight forecasts modified to include weather forecasts. A simulation analysis. Phytopathology, 83, 103-108. 
Regis P., Kowalski M.S., Thompson P.P., Kinchington P.R., Gordon J.Y. (2006)

Evaluation of the smartcycler II system for real-time detection of viruses and chlamydia from ocular specimens. Archives of Ophthalmology, 124, 1135-1139.

Reiger T. (2013) Spore traps help detect powdery mildew. Vineyard and Winery Management, May/June, pp 64-68. http://vwmonline.com/images/kreck/2013MJ RIEGER MILDEW.pdf

Ribeiro O.K. (1978) A source book of the genus Phytophthora. Vaduz, Liechtenstein: J. Cramer.

Ristaino J.B. (1991) Influence of rainfall, drip irrigation, and inoculum density on the development of Phytophthora root and crown rot epidemics and yield in bell pepper. Phytopathology 81:922-929.

Robideau G.P., Caruso F.L., Oudemans P.V., McManus, Renaud M.A., Auclair M.E., Bilodeau G.J., Yee D., Désaulniers N.L., Deverna J.W., Lévesque C.A. (2008) Detection of cranberry fruit rot fungi using DNA array hybridization. Canadian Journal of Plant Pathology, 30, 226-240.

Robideau G.P., De Cock A.W.A.M., Coffey M.D., Voglmayr H., Brouwer H., Bala K., Chitty D.W., De Saulniers N., Eggertson Q.A., Gachon C.M., Hu C.-H., Küpper F.C., Rintoul T.L., Sarhan E., Verstappen E.C.P., Zhang Y., Bonants P.J.M., Ristaino J.B., Lévesque C.A. (2011) DNA barcoding of oomycetes with cytochrome $c$ oxidase subunit I and internal transcribed spacer. Molecular Ecology Resources, 11, 1002-1011

Saiki R.K., Gelfand D.H., Stoffel S., Scharf S.J., Higuchi R., Horn G.T., Mullis K.B., Erlich H.A. (1988) Primer-directed enzymatic amplification of DNA with a thermostable DNA polymerase. Science, 239, 487-491.

Sapkota R., Nicolaisen M. (2015) An improved high throughput sequencing method for studying oomycete communities. Journal of Microbiological Methods, 110, 3339.

Savazzini F., Longa C.M., Pertot I., Gessler C. (2008) Real-time PCR for detection and quantification of the biocontrol agent Trichoderma atroviride strain SC1 in soil. Journal of Microbiological Methods 73:185-194.

Schaad N.W., Frederick R.D. (2002) Real-time PCR and its application for rapid plant disease diagnostics. Canadian Journal of Plant Pathology, 24, 250-258.

Schena L., Hughes K.J.D., Cooke D.E.L. (2006) Detection and quantification of Phytophthora ramorum, $P$. kernoviae, $P$. citricola and $P$. quercina in symptomatic leaves by multiplex real-time PCR. Molecular Plant Pathology, 7, 365-379. 
Scherm H., van Bruggen A.H.C. (1995) Concurrent spore release and infection of lettuce by Bremia lactucae during mornings with prolonged leaf wetness. Phytopathology, 85, 552-555.

Schoch C.L., Seifert K.A., Huhndorf S., Robert V., Spouge J.L., Lévesque C.A., Chen W. and the Fungal Barcoding Consortium (2012) Nuclear ribosomal internal transcribed spacer (ITS) region as a universal DNA barcode marker for fungi. Proceedings of the National Academy of Sciences of the United States of America, 109, 6241-6246.

Schroeder K.L., Martin F.N., deCock A.W.A.M., Lévesque C.A., Spies C.F.J., Okubara P.A., Paulitz T.C. (2013) Molecular detection and quantification of Pythium species: evolving taxonomy, new tools, and challenges. Plant Disease, 97, 4-20.

Schuster S.C. (2008) Next-generation sequencing transforms today's biology. Nature, 5, 16-18.

Scibetta S., Schen L., Chimento A., Cacciola S.O., Cooke D.E.L. (2012) A molecular method to assess Phytophthora diversity in environmental samples. Journal of Microbiological Methods, 88, 356-368.

Serrano M.S., De Vita P., García L.V., Ramo C., Aponte C., Gómez-Aparicio L., Sánchez M.E. (2011) Influence of bird-induced soil fertility gradients on oomycete distribution in a threatened Quercus suber population. In Multitrophic Interactions in Soil, Bulletin 71 pp. 135-139. Eds B.B. Landa, J.A. Navas-Cortés, M. MontesBorrego, C. Steinberg. Córdoba, Spain: International Organisation for Biological and Integrated Control/ West Palaearctic Regional Section.

Shan G. (2011) Immunoassays in Agricultural Biotechnology. Hoboken, NJ, USA: John Wiley \& Sons, Inc.

Shock J.L., Fischer K.F., DeRisis J.L. (2007) Whole-genome analysis of mRNA decay in Plasmodium falciparum reveals a global lengthening of mRNA half-life during the intra-erythrocytic development cycle. Genome Biology, 8, R134. DOI:10.1186/gb-2007-8-7-r134

Singh R.P., Singh U.S. (1995) Molecular methods in plant pathology. Boca Raton, FL, USA: CRC Press Inc.

Skelsey P., Kessel G.J.T., Holtslag, A.A.M., Moene, A.F., van der Werf, W. (2009) Regional spore dispersal as a factor in disease risk warnings for potato late blight: a proof of concept. Agricultural and Forest Meteorology 149:419-30.

Skottrup P.,Niclaisen M., Justesen A.F. (2007) Rapid determination of Phytophthora infestans sporangia using a surface plasmon resonance immunosensor. Journal of Microbiological Methods 68:507-515. 
Smith M.L. Bruhn J.N. Anderson J.B. (1982) The fungus Armillaria bulbosa is among the largest and oldest living organisms. Nature 356:428-431.

Songe M.M., Willems A., Wiik-Nielsen J., Thoen E., Evensen $\varnothing$., Van West P., Skaar I. (2015). Saprolegnia diclina IIIA and S. parasitica employ different infection strategies when colonizing eggs of Atlantic salmon, Salmo salar L. Journal of Fish Diseases DOI: 10.1111/jfd.12368.

Steffan R.J., Atlas R.M. (1991) Polymerase chain reaction: applications in environmental microbiology. Annual review of microbiology, 45, 137-161.

Stewart-Wade S. (2011) Plant pathogens in recycled irrigation water in commercial plant nurseries and greenhouses: their detection and management. Irrigation Science, 29, 267-297.

Strand D.A., Jussila J., Viljamaa-Dirks S., Kokko H., Makkonen J., Holst-Jensen A., Viljugrein H., Vrålstad T. (2012) Monitoring the spore dynamics of Aphanomyces astaci in the ambient water of latent carrier crayfish. Veterinary Microbiology, 160, 99-107.

Suffert F., Montfort F. (2007) Demonstration of secondary infection by Pythium violae in epidemics of carrot cavity spot using root transplantation as a method of soil infestation. Plant Pathology, 56, 588-594.

Tambong J.T., De Cock A.W.A.M., Tinker N.A., Lévesque C.A. (2006) Oligonucleotide array for identification and detection of Pythium Species. Applied and Environmental Microbiology, 72, 2691-2706.

Themann K., Werres S., Diener H.-A., Lüttmann R. (2002) Comparison of different methods to detect Phytophthora spp. in recycling water from nurseries. Journal of Plant Pathology 84, 41-50.

Theron M., Hesketh R.L., Subramanian S., Rayner J.C. (2010) An adaptable twocolor flow cytometric assay to quantitate the invasion of erythrocytes by Plasmodium falciparum parasites. Cytometry Part A. 77, 1067-1074.

Thiessen L. D., Keune J. A., Neill T. M., Turechek W. W., Grove G. G., Mahaffee, W. F. (2015). Development of a grower-conducted inoculum detection assay for management of grape powdery mildew. Plant Pathology. DOI:

10.1111/ppa.12421.

Thornton C.R., Groenhof A.C., Forrest R., Lamotte R.A. (2004) One-Step, Immunochromatographic Lateral Flow Device Specific to Rhizoctonia solani and Certain Related Species, and Its Use to Detect and Quantify R. solani in Soil. Phytopathology, 94, 280-288.

Thornton C.R., Pitt D., Wakley G.E. Talbot N.J. (2002) Production of a monoclonal antibody specific to the genus Trichoderma and closely related fungi, and its use 
to detect Trichoderma spp. in naturally infested composts. Microbiology 148:12631279.

Thornton C.R., Wills O.E. (2013) Immunodetection of fungal and oomycete pathogens: Established and emerging threats to human health, animal welfare and global food security. Critical Reviews in Microbiology, 41, 27-51.

Tomlinson J.A., Boonham N., Hughes K.J.D., Griffin R.L., Barker I. (2005) On-Site DNA Extraction and Real-Time PCR for Detection of Phytophthora ramorum in the Field. Applied Environmental Microbiology, 71, 6702-6710.

Tomlinson J.A., Dickinson M.J., Boonham N. (2010) Rapid detection of Phytophthora ramorum and $\mathrm{P}$. kernoviae by two-minute DNA extraction followed by isothermal amplification and amplicon detection by generic lateral flow device.

Phytopathology, 110, 143-149.

Tooley P.W., Martin F.N., Carras M.M., Frederick R.D. (2006) Real-time fluorescent polymerase chain reaction detection of Phytophtho raramorum and Phytophthora pseudosyringae using mitochondrial gene regions. Phytopathology, 96, 336-345.

Tsai G.-J., Cousin M.A. (1993) Partial purification and characterization, of mold antigens commonly found in foods. Applied and Environmental Microbiology, 59, 2563-2571.

Tsao P.H. (1960) A serial dilution end-point method for estimating disease potentials of citrus Phytophthoras in soil. Phytopathology, 50, 717-724.

Tsao P.H. (1983). Factors affecting isolation and quantification of Phytophthora from soil. In Phytophthora: Its Biology, Taxonomy, Ecology and Pathology, pp. 219236. Eds D.C. Erwin, S. Bartnicki-Garcia and P.H. Tsao. St. Paul, MN, USA: American Phytopathological Society.

Tuffs S., Oidtmann B. (2011) A comparative study of molecular diagnostic methods designed to detect the crayfish plague pathogen Aphanomyces astaci. Veterinary Microbiology, 153, 343-353.

Vallance J., Le Floch G., Déniel F., Barbier G., Lévesque A., Rey P. (2009) Influence of Pythium oligandrum biocontrol on fungal and oomycete population dynamics in the rhizosphere. Applied and Environmental Microbiology, 75, 4790-4800.

Van der Plaats-Niterink A.J. (1981) Monograph of the genus Pythium. Studies in Mycology 21. Baarn, Netherlands: Centraalbureau voor Schimmelcultures.

Vannini A., Bruni N., Tomassini A., Franceschini S., Vettraino A.-M. (2013) Pyrosequencing of environmental soil samples reveals biodiversity of the Phytophthora resident community in chestnut forests. FEMS Microbiology Ecology, 85, 433-442. 
Van West P. (2006) Saprolegnia parasitica an oomycete pathogen with a fishy appetite: new challenges for an old problem. Mycologist, 20, 99-104.

Vettraino A. M., Tomassini A., Vannini A. (2010) Use of mRNA as an indicator of the viability of Phytophthora cambivora. Acta Horticulturae, 866, 431-434.

Villa N.O., Kageyama K., Asano T., Suga H. (2006). Phylogenetic relationships of Pythium and Phytophthora species based on ITS rDNA, cytochrome oxidase II and beta-tubulin sequences. Mycologia 98:410-422.

Viudes A., Perea S., Lopez-Ribot J.L. (2001) Identification of continuous B-Cell epitopes on the protein moiety of the 58-Kilodalton cell wall manno protein of Candida albicans belonging to a family of immunodominant fungal antigens. Infection and Immunity, 69, 2909-2919.

Voller A., Bidwell D., Bartlett A. (1976) Microplate immunoassay for the immunodiagnosis of virus infections. In Manual of Clinical Immunology, pp. 506512. Eds N.R. Rose and H.H. Friedman. Washington DC, USA: American Society for Microbiology.

Wakeham, A.J. (2014). The development and application of immunological tests within horticultural crop disease management systems. Ph.D. thesis. University of Wocester, Henwick Grove, Worcester, U.K.

Wakeham A.J., Kennedy R. (2010) Risk Assessment Methods for the Ringspot Pathogen Mycosphaerella brassicicola in Vegetable Brassica Crops. Plant Disease, 94, 851-859.

Wakeham A.J., Kennedy R.,McCartney H.A. (2004) The collection and retention of a range of common airborne spore types trapped directly into microtiter wells for enzyme-linked immunosorbent analysis. Journal of Aerosol Science 35, 835-850

Wakeham A.J., Keane G., Proctor M., Kennedy R. (2012) Monitoring infection risk for air and soil borne fungal plant pathogens using antibody and DNA techniques and mathematical models describing environmental parameters. In Microbes in Applied Research: Current Advances and Challenges, pp. 152-156. Ed A. Mendez-Vilas. Singapore: World Scientific Publishing Co. Pte. Ltd,.

Wakeham A.J., Pettitt T.R., White J.G. (1997) A novel method for detection of viable zoospores of Pythium in irrigation systems. Annals of Applied Biology, 131, 427435.

Wakeham A.J., White J.G. (1996) Serological detection in soil of Plasmodiophora brassicae resting spores. Physiological and Molecular Plant Pathology, 48, 289303.

Wakeham A.J., Lewis, M., Keane G., Edwards E., Petch G., John S. (2015) Validation of the clubroot lateral flow in UK commercial Brassica cropping 
systems. Final Report on HDC Project CP099A. Stoneleigh Park, Warwickshire, UK: AHDB Horticulture.

Wallace A., Williams N.A., Lowe R., Harrison J.G. (1995) Detection of Spongospora subterranea using monoclonal antibodies in ELISA. Plant Pathology, 44, 355-365.

Way J.S., Josephson K.L., Pillai S.D., Abbaszadegan M., Gerba C.P., Pepper I.L. (1993) Specific detection of Salmonella spp. by multiplex polymerase chain reaction. Applied and Environmental Microbiology, 59, 1473-1479.

Wedgwood E. (2014) Baiting and diagnostic techniques for monitoring Phytophthora spp. and Pythium spp. in irrigation water on ornamental nurseries. Final Report on HDC Project HNS/PO188. Stoneleigh Park, Warwickshire, UK: AHDB Horticulture.

Werres S, Ghimire SR, Pettitt TR. (2014) Baiting assays for detection of Phytophthora species in irrigation water. In Biology, Detection and Management of Plant Pathogens in Irrigation Water, pp. 125-138. Eds C.X. Hong, G.W. Moorman, W. Wohanka and C. Büttner. St Paul, MN, USA: American Phytopathological Society.

Weste G., Vithanage K. (1977) Microbial populations of three forest soils: seasonal variations and changes associated with Phytophthora cinnamomi. Australian Journal of Botany 25:377-383.

West J.S., Kimber R.B.E. (2015) Innovations in air sampling to detect plant pathogens. Annals Applied Biology 166, 4-17

White J.G., Lyons N.F., Petch G.M. (1995) Development of a diagnostic test for the pathogens which cause cavity spot of carrot. Final Report on HDC Project FV05A. East Malling, Kent, UK: Horticultural Development Council.

White J.G., Lyons N.F., Petch G.M. (1996) Development of a commercial diagnostic test for the pathogens which cause cavity spot of carrot. BCPC Symposium Proceedings No. 65: Diagnostics in Crop Protection. Pp. 343-348.

White J.G., Petch G.M., Hiltunen L.H. (1997) Development of a commercial diagnostic test for cavity spot. Carrot Country, Fall 1997, 7, 9, 10, 23.

White J.G., Wakeham A.J. (1987) Responses of Pythium spp. associated with cavity spot of carrots to metalaxyl and related fungicides. Tests of Arochemicals and Cultivars $A A B, \mathbf{1 1 0}$ (supplement), 52-53.

White J.G., Wakeham A.J., Petch G.M. (1992) Deleterious effect of soil applied metalxyl and mancozeb on the mycoparasite Pythium oligandrum. Biocontrol Science and Technology, 2, 335-340. 
Will K.W., Rubinoff D. (2004) Myth of the molecule: DNA barcodes for species cannot replace morphology for identification and classification. Cladistics, 20, 4755.

Wilson I.G. (1997) Inhibition and facilitation of nucleic acid amplification. Applied and Environmental Microbiology, 63, 3741-3751.

Wong R.C., Tse H.Y. (2009) Lateral flow immunoassay. New York, USA: Humana Press, Springer. ISBN978-I-58829-908-6.

Yalow R.S., Berson S.A. (1959) Assay of plasma insulin in human subjects by immunological methods. Nature, 184, 1648-1649.

Yuen G.Y., Craig M.L., Avila F. (1993) Detection of Pythium ultimum with a speciesspecific monoclonal antibody. Plant disease, 77, 692-698. .

\section{Figure Legends}

Figure 1: Positive LFD test strips; on the left a strong positive for Phytophthora, showing clear control $(\mathrm{C})$ and test $(\mathrm{T})$ bands, and on the right a very weak positive for Pythium.

Figure 2: Developed ZTI membrane showing trapped and germinated Phytophthora zoospore cysts.

Figure 1: 




Figure 2:

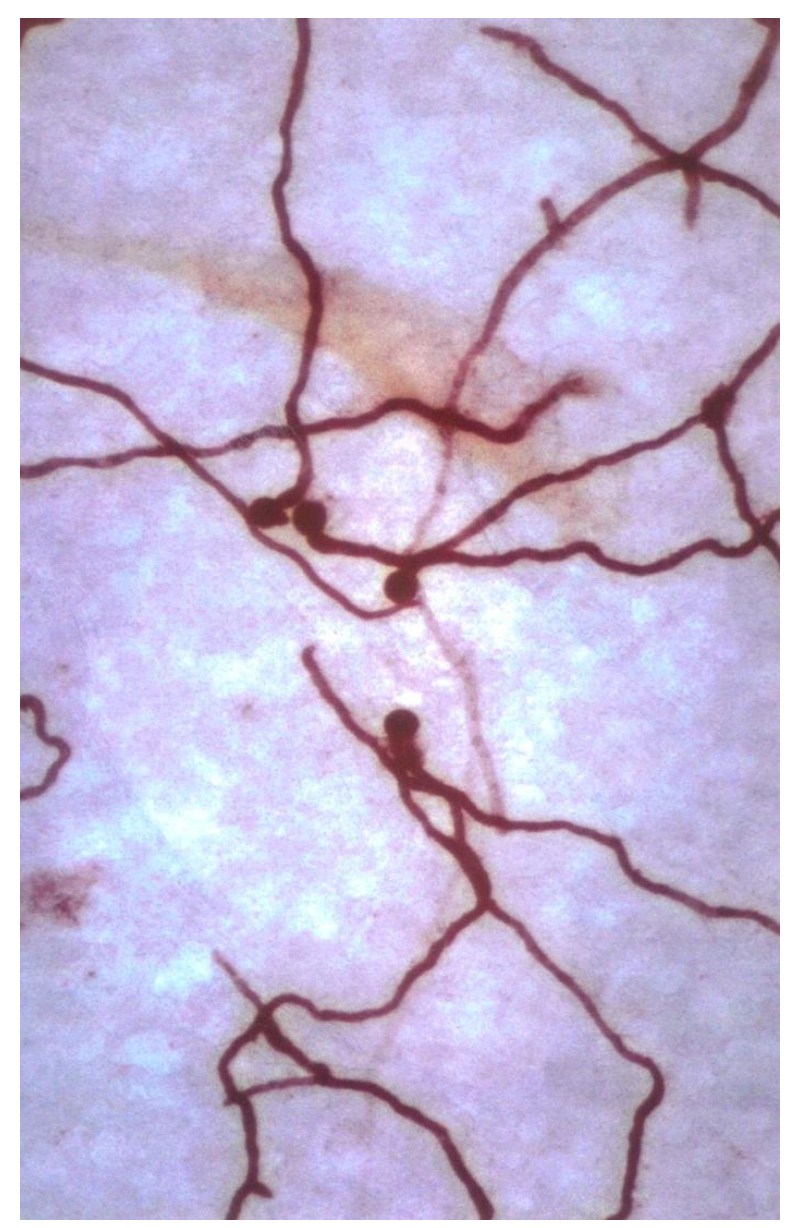

